\title{
A LEGITIMIDADE CONSTITUCIONAL DO ENSINO RELIGIOSO CONFESSIONAL EM ESCOLAS PÚBLICAS NO BRASIL: ANÁLISE DA AÇÃO DIRETA DE INCONSTITUCIONALIDADE 4.439 A PARTIR DA LAICIDADE POSITIVA EM BENTO XVI
}

\author{
VICTOR SALES PINHEIRO ${ }^{1}$ \\ VICTOR CLÁUDIO ARAÚJO PICANÇO DA SILVA²
}

\begin{abstract}
Resumo:
Este artigo aborda a legitimidade constitucional do ensino religioso em escolas públicas no Brasil, a partir da análise dos argumentos favoráveis (considerados laicos) e contrários (considerados laicistas) debatidos na Ação Direta de Inconstitucionalidade 4439, que defende a adoção de um modelo não confessional de ensino. Para tanto, aborda-se o horizonte do problema da secularização, relacionando o direito à liberdade religiosa, o pluralismo religioso e o Estado Laico. Em seguida, apresenta-se o referencial teórico de Bento XVI, cujo Magistério é analisado a partir da distinção entre laicidade positiva, em que o Estado não só protege o direito à liberdae religiosa, mas o promove pela colaboração com entidades religiosas, e o laicismo militante, que defende uma cosmovisão iluminista que visa a privatizar a religião e neutralizá-la no espaço público.

Palavras-chave: secularização, direito à liberdade religiosa, ADI 4439, laicidade positiva, Bento XVI

Abstract:

This article addresses the constitutional legitimacy of religious education in public schools in Brazil, based on the analysis of the favorable (considered secular) and contrary (considered secularist) arguments discussed in Direct Action of Unconstitutionality 4439, which defends the adoption of a non-confessional model of religious education. To this end, it deals with the problem of secularization, related to the right to religious freedom, religious pluralism and the Secular State. Then, the theoretical framework of Benedict XVI is presented, whose teachings is analyzed from the distinction between positive secularity, in which the State not only protects the right to religious liberty, but promotes it through collaboration with religious entities, and militant secularism, which defends an Enlightenment worldview that aims to privatize religion and neutralize it in the public space.
\end{abstract}

Keywords: secularization, right to religious freedom, adi 4439, positive secularity, Benedict XVI

DOI: 10.7764/RLDR.9.115

\footnotetext{
${ }^{1}$ Professor e pesquisador da Universidade Federal do Pará e do Centro Universitário do Pará (Brasil). Mestre e Doutor em Filosofia. Coordenador do Grupo de Pesquisa Tradição da Lei Natural (CNPq-Brasil) Área de experiência: Filosofia política, moral e jurídica. E-mail: vvspinheiro@yahoo.com.br

2 Especialista em Direito Administrativo pela Pontifícia Universidade Católica de Minas Gerais (Brasil). Graduado em Direito pela Universidade Federal do Pará (Brasil). Membro do Grupo de Pesquisa Tradição da Lei Natural (CNPq-Brasil). Analista judiciário do Ministério Público do Estado do Pará. Área de experiência: Direito constitucional, Doutrina Social da Igreja e Ideologias políticas.
} 
Victor Sales Pinheiro \& Victor Cláudio Araújo Picanço Da Silva: A legitimidade constitucional do ensino religioso confessional em escolas públicas no Brasil: análise da ação direta de inconstitucionalidade 4.439 a partir da laicidade positiva em Bento XVI

\section{INTRODUÇÃO}

Em seu artigo 210, § 1ํㅡ, a Constituição Federal do Brasil (CF) assegura o ensino religioso facultativo nas escolas públicas de ensino fundamental. Até a década passada, a compreensão de que o Estado colabora com entidades religiosas para a formação espiritual dos cidadãos não havia sido questionada. O direito à liberdade religiosa do aluno da rede pública é garantido pela possibilidade de ter formação escolar religiosa, caso queira, na sua própria escola, além de aprender sobre o fenômeno religioso em disciplinas seculares como História, Geografia, Literatura, Sociologia e Filosofia.

Porém, recentemente, a legitimidade dessa prática foi questionada: O Estado Constitucional deve oferecer o ensino religioso confessional, ainda que facultativo, em escolas públicas? Este artigo investiga o debate jurídico e filosófico deflagrado pela Ação Direta de Inconstitucionalidade (ADI) n. 4.439, em que a Procuradoria-Geral da República (PGR) questiona a legitimidade do ensino religioso em escolas públicas, a fim de conferir interpretação conforme à Constituição Federal a dispositivos da Lei de Diretrizes e Bases da Educação e ao acordo firmado entre o Brasil e a Santa Sé (Decreto no 7.107/2010).

Em 2017, o Supremo Tribunal Federal (STF) julgou improcedente, por seis votos a cinco, o pedido da PGR, interpretando como legítimo que as escolas públicas ofereçam ensino religioso confessional, de forma facultativa. A divisão da Corte Suprema brasileira revela uma polarização no seio da sociedade sobre o sentido da laicidade do Estado e o papel da religião no espaço público.

A fim de contribuir para elucidação dos conceitos desse debate jurídico, político e religioso, neste artigo, apresenta-se esse caso jurídico controverso, elucidando-o a partir dos conceitos de secularização, laicidade, direito à liberdade religiosa, com base no magistério do Papa Bento XVI, que nos serve de referencial teórico para refletir sobre as distinções conceituais e práticas da laicidade (sã ou positiva) e laicismo.

Nesse contexto, este artigo se estrutura em três seções interdependentes. Na próxima (2), apresenta-se o horizonte do problema, introduz-se o problema histórico-conceitual da secularização, sublinhando o desafio metodológico de seu estudo interdisciplinar, e a subversão laicista do direito à liberdade religiosa.

Em seguida (3), explora-se o referencial teológico da laicidade positiva no magistério do Papa Bento XVI que permite discernir, conceitualmente, a decisão jurídica da Corte Suprema brasileira, em favor da legitimidade constitucional do modelo confessional de ensino religioso. 
ISSN 0719-7160

Por fim (4), apresenta-se a problemática jurídica da ADI n. 4.439, em que a ProcuradoriaGeral da República questiona a legitimidade do ensino religioso em escolas públicas, a fim de conferir interpretação conforme à Constituição Federal a dispositivos da Lei de Diretrizes e Bases da Educação e ao acordo firmado entre o Brasil e a Santa Sé (Decreto 7.107/2010).

\section{HORIZONTE DO PROBLEMA: SECULARIZAÇÃO, LIBERDADE RELIGIOSA E LAICISMO}

As profundas transformações que se abateram sobre o Ocidente ao longo do último século pautaram novas concepções da vida social: relações familiares, profissionais, étnicas e religiosas. Nada passou incólume pelo furacão cultural, político e econômico do século XX, que, consumando a modernidade, abandonou as formas tradicionais de vida.

Com efeito, as sucessivas guerras mundiais, bem como o advento de regimes totalitários, e a utilização do aparelho de Estado para perseguições de cunho étnico e religioso contribuíram, paradoxalmente, para a posterior afirmação dos direitos humanos e formação do Estado Democrático de Direito, com a limitação jurídica do poder estatal e a ampliação dos direitos dos indivíduos.

Esses eventos históricos, muitas vezes traumáticos, levaram à concepção de que, para se alcançar certa paz social que permita o pleno desenvolvimento humano, isto é, a realização, enquanto pessoa, dos indivíduos de uma determinada comunidade política, é necessário um ambiente de liberdade e respeito pela pessoa humana, tanto por parte do Estado (sentido vertical), quanto por parte dos particulares (sentido horizontal), considerando ainda a sua inserção no contexto da globalização, que estimula o contato e interação as mais diversas culturas e convicções, sobretudo por meio do mercado de bens e serviços.

Assim, mais notadamente no período do Pós-Guerra, com a vitória dos Aliados e a pretensão de universalização da democracia liberal, passou-se a exigir dos Estados a postura de neutralidade no âmbito religioso (laicidade), com a consagração da liberdade de religião como direito fundamental. No contexto da Guerra Fria, essa postura liberal estava em franco contraste com o mundo socialista, que ainda tendia para a laicização do espaço público, subtraindo-o de toda interferência religiosa. 
Victor Sales Pinheiro \& Victor Cláudio Araújo Picanço Da Silva: A legitimidade constitucional do ensino religioso confessional em escolas públicas no Brasil: análise da ação direta de inconstitucionalidade 4.439 a partir da laicidade positiva em Bento XVI

Porém, no século XXI, encontra-se em crise a própria ideia de liberal de laicidade, como o caso do ensino público confessional em estudo demonstra, pois as opiniões se dividem radicalmente sobre o papel do Estado na promoção ou proteção da do direito à liberdade religiosa.

Ou seja, o debate das sociedades seculares e liberais contemporâneas é sobre o risco da neutralização do direito humano à liberdade religiosa por uma postura laicista do Estado, que interfere positivamente na diminuição da religião na sociedade, privando-a dos meios de sustentação jurídico e social que antes sustentava o gozo dessa liberdade.

\subsection{O desafio metodológico do estudo interdisciplinar da secularização}

A religião é um fenômeno teológico, sociológico e psicológico altamente complexo, pois envolve todas as dimensões da vida humana em sociedade e exige uma reflexão necessariamente interdisciplinar, pois ela não se reduz a nenhum dos seus elementos constitutivos, seja a teologia, a história, a cultura, a ética, o direito ou a política.

Assim, diante desse quadro social polêmico e conflitivo da liberdade religiosa e do Estado laico, surgem numerosas interpretações teóricas suscetíveis de pesquisa. Trata-se de um desafio não só social e político, mas também intelectual e acadêmico, uma vez que o pluralismo não é só religioso, moral e político, mas também epistemológico.

Em linhas gerais, e sem levar em conta as múltiplas abordagens propriamente teológicas, a discussão acadêmica atual sobre a religião pode ser categorizada em três tipos de análise: a da ciência social, a da filosofia da história e a da teoria política normativa. Naturalmente, cada um desses eixos pressupõe argumentos dos outros, quando não os exploram diretamente, cujo caso emblemático é o de Charles Taylor (2010), que desenvolve uma teoria política normativa a partir da sociologia histórica, deixando entrever determinada filosofia da história.

(1) Tendo Émile Durkheim e Max Weber como autores paradigmáticos, a primeira é a da ciência social, sobretudo a história e a sociologia, mas também a economia e a antropologia, que investiga o processo de secularização na modernidade ocidental, considerando as mudanças culturais do Renascimento Cultural, da Reforma Protestante, da Revolução Científica, das Revoluções Burguesas e Socialistas e das Revoluções Industriais. O objetivo desse tipo de investigação é delinear quais seriam os traços distintivos da sociedade moderna secular em comparação com as sociedades pré-modernas, religiosas e tradicionais (FAZIO, 2012a). 


\section{ISSN 0719-7160}

(2) Incorporando muitos dados empíricos da primeira análise, a segunda é a da filosofia da história, que interpreta esse processo histórico verificando em que medida a modernidade é herdeira da tradição religiosa, comparando a linguagem, os símbolos e as instituições medievais com as modernas, a fim de rastrear as suas ressonâncias e rupturas. Nesse filão, podem-se enquadrar as reflexões de autores como Carl Schmitt, Karl Löwith, Leo Strauss, Eric Voegelin e René Girard (MARRAMAO, 1994).

(3) Adotada por este Artigo e pela maioria das abordagens desse tema na Academia de Direito, a terceira é a análise da filosofia normativa, presente na teoria política, jurídica e moral, que refletem sobre os princípios de uma sociedade justa, como a liberdade e a igualdade de direitos. Autores como John Rawls, Ronald Dworkin, Michael Walzer, Joseph Raz e John Finnis pertencem a essa categoria de investigação (ARAÚJO, 2012).

A distinção entre era secular, processo de secularização e secularismo importa para a metodologia teórica adotada por este Artigo, qual seja, (1) a da ciência social e (2) da teoria jurídico-política normativa. Ademais, essa distinção é relevante para distinguir, de forma preliminar, três modelos básicos de relação entre Estado e religião (OLLERO, 2013):

(1) um Estado confessional, que professa uma religião oficial de maneira pública, sem necessariamente torná-la obrigatória aos cidadãos, como é o caso da Inglaterra Anglicana;

(2) um Estado aconfessional, não-confessional ou laico, que não confessa nenhuma religião, garantindo, assim, a liberdade religiosa dos cidadãos; e

(3) um Estado anticonfessional, laicista ou ateu, que considera a religião um mal a ser combatido, visando a libertar a sociedade da influência religiosa com medidas ativas de desclericalização, de redução ou neutralização da religião no âmbito político e social, como no caso da dos Estados oriundos das Revoluções Francesa e Comunista. Esses Estados promovem ativamente a laicização, removendo, por exemplo, todos os símbolos religiosos da esfera pública.

Por isso, autores como Santamaria (2013) distinguem laicidade de laicismo, sendo a primeira uma postura política de respeito e tolerância à crença religiosa, mesmo em sua dimensão pública e social, ao passo que a segunda seria uma postura hostil à religião, que visa a neutralizá-la ativamente, reduzindo-a ao âmbito meramente privado e insignificante do ponto de vista público e político, como se explica adiante. 
Victor Sales Pinheiro \& Victor Cláudio Araújo Picanço Da Silva: A legitimidade constitucional do ensino religioso confessional em escolas públicas no Brasil: análise da ação direta de inconstitucionalidade 4.439 a partir da laicidade positiva em Bento XVI

\subsection{O processo histórico de secularização}

O acelerado processo de secularização e o consequente enfraquecimento do fator religioso ameaçou a integração e unidade política das sociedades, cujo vínculo fundamental era a religião. Como assinala Ayuso (2008, p. 17), as Constituições dos Estados Modernos emergiram para enfrentar esse desafio.

Isto é, na sociedade cosmopolita, marcada pela dinâmica da modernidade, em que as tradições perderam espaço na vida social e houve uma acentuação do papel da consciência individual, o Estado passou a exercer esta tarefa unificadora, tendo as virtudes cívicas substituído as virtudes religiosas no espaço público.

Como a religião não era mais um fator de unidade, antes, pelo contrário, de desunião e mesmo de guerra, o Estado liberal moderno precisou adotar um ecumenismo e deflacionar consideravelmente o teor metafísico de suas políticas públicas, a fim de se subtrair do conflito religioso instalado entre os indivíduos e respectivas comunidades religiosas. Este processo é explicado por Thomas Joseph White (2006) nos seguintes termos:

Os conflitos sobre dogmas religiosos no período cristão pré-iluminista da Civilização Europeia originaram a percepção de que nossa vida pública não deve ser formada por obrigações inegociáveis. A fim de seguir um caminho pluralista, pacífico, os governos democráticos precisam renunciar às suas alianças com credos religiosos e se distanciar de profundas considerações metafísicas sobre a realidade e sobre os fins do ser humano. $O$ espaço para mútua concórdia surge somente quando há uma praça pública em que rivais metafísicos podem conviver em tolerância mútua. Hoje, esta visão se traduz num princípio teórico simples. O Estado moderno deve praticar um "ecumenismo" de denominadores teóricos comuns: este não adere a nenhum credo em particular, de modo a permitir as múltiplas crenças de todos aqueles que habitam o espaço público.

Neste trecho, White (2006) explica em que medida a ordem e a paz social dependem da tolerância e ao pluralismo religioso, a partir de um Estado Laico que não onere suas políticas com nenhum fundamento metafísico controverso, a fim de não renovar o conflito social que ele surgiu para resolver. Ecumenista e metafisicamente minimalista, o Estado liberal moderno deve se abster de participar nas decisões religiosas dos indivíduos e das comunidades religiosas para que não ingresse na disputa religiosa em que a sociedade plural já está imersa.

A laicidade do Estado moderno, portanto, afetou diretamente o processo de secularização da sociedade, de diminuição da influência e protagonismo público da religião, articulado ao 
ISSN 0719-7160

desenvolvimento científico das sociedades industriais, e ao espírito da ordem econômico-social (capitalismo).

Conforme a clássica leitura de Weber, a racionalização do mundo moderno, que promoveu o desencantamento do mundo, articula um fator político a um científico, além da relação entre capitalismo e protestantismo. No âmbito político, o Estado não reclama mais autoridade tradicional ou carismática, mas racional-legal, o que significa também neutra de justificações históricoreligiosas. Por outro lado, a ciência moderna visa a racionalizar a explicação das causas materiais dos fenômenos naturais, o que permitiu o avanço da tecnologia e da industrialização.

Juntamente com a noção de "desencantamento do mundo", a reflexão sobre a secularização inspirou formulações mais recentes, que a vinculam ao processo de urbanização e que ressaltam um aspecto de particular interesse a este Artigo, o pluralismo. Autor referencial na compreensão desta temática, Catroga (2006, p. 36) explica a transformação sociológica da "comunidade" para a "sociedade", no contexto da urbanização que acabou por desintegrar a vida tradicional, em que a comunidade agrária se unia pela ligação comum ao solo, aos antepassados e a Deus.

O resultado é que a vida urbana é marcada pelo individualidade, despersonalização e multiplicação dos papéis sociais, entronizando o princípio da liberdade individual, inclusive a liberdade de mudar de vida ou de religião, divorciando-se da comunidade em que se nasceu. Tratase do surgimento do anonimato e impessoalidade das massas, pautado na tolerância que se aproxima da indiferença e na vontade contratual como matriz das relações sociais. Nesse quadro, neutralizam-se "as sanções morais costumeiras, reproduzidas e impostas por vínculos de longa duração, típicos do viver em comunidade." (CATROGA, 2006, p. 36).

Surge, assim, o moderno paradigma do individualismo moral e jurídico, em que a liberdade individual é tutelada por direitos, oponíveis à coletividade e protegidos pelo próprio Estado, sendo o direito individual à liberdade religiosa indissociável das demais liberdades cívicas conquistadas na modernidade, como a liberdade de expressão, de locomoção e de associação.

\subsection{Afirmação jurídica do direito humano à liberdade religiosa}

Na gradativa afirmação histórica dos direitos humanos, houve uma mudança de paradigma no campo das relações entre Estado e religião. Isso porque, até meados do século XX, predominava 
Victor Sales Pinheiro \& Victor Cláudio Araújo Picanço Da Silva: A legitimidade constitucional do ensino religioso confessional em escolas públicas no Brasil: análise da ação direta de inconstitucionalidade 4.439 a partir da laicidade positiva em Bento XVI

uma relação de âmbito sobretudo institucional, em que o Estado garantia certos direitos às igrejas e comunidades religiosas.

Rafael Llano Cifuentes (1989, p. 211) explica que, até o século XX, as relações entre a Igreja e o Estado deram-se mais ao nível de autoridade, de relação entre os detentores dos poderes públicos de ambas as instituições, como um Governador e um Bispo. Ou seja, a interação entre eles era mais passiva e entre as respectivas autoridades hierárquicas.

Posteriormente, contudo, ante certos acontecimentos históricos, como as violações presentes nos regimes totalitários que emergiram na primeira metade do século $\mathrm{XX}$ e as atrocidades da II Guerra Mundial, surgiu a preocupação em assegurar ao indivíduo a liberdade de exercício da religião, sendo esta liberdade considerada um direito fundamental. Nota-se aqui uma transição paradigmática de uma concepção pública e comunitária de religião para um modelo mais individualista e subjetivo da prática religiosa. Com efeito, a Declaração Universal de Direitos Humanos da Organização das Nações Unidas, de 1948, dispõe:

\section{Artigo 18}

Todo o homem tem direito à liberdade de pensamento, consciência e religião; este direito inclui a liberdade de mudar de religião ou crença e a liberdade de manifestar essa religião ou crença, pelo ensino, pela prática, pelo culto e pela observância, isolada ou coletivamente, em público ou em particular. (ONU, 1948)

No mesmo sentido, a Igreja Católica acolheu essa transformação paradigmática, articulando-a com o princípio da dignidade da pessoa humana, assimilando a linguagem dos direitos humanos e a defesa da liberdade religiosa. Trata-se, sem dúvida, de uma mudança considerável na abordagem que a Instituição apresentou até então, uma "verdadeira transmutação de valores", no parecer de Cifuentes (1989, p. 212). A Declaração Dignitatis Humanae sobre a Liberdade Religiosa, do Concílio Vaticano II, afirma:

2. Este Concílio Vaticano declara que a pessoa humana tem direito à liberdade religiosa. Esta liberdade consiste no seguinte: todos os homens devem estar livres de coacção, quer por parte dos indivíduos, quer dos grupos sociais ou qualquer autoridade humana; e de tal modo que, em matéria religiosa, ninguém seja forçado a agir contra a própria consciência, nem impedido de proceder segundo a mesma, em privado e em público, só ou associado com outros, dentro dos devidos limites. Declara, além disso, que o direito à liberdade religiosa se funda realmente na própria dignidade da pessoa humana, como a palavra revelada de Deus e a própria razão a dão a conhecer. Este direito da pessoa humana à liberdade religiosa na ordem jurídica da sociedade deve ser de tal modo reconhecido que se torne um direito civil. (VATICANO, 1965) 


\section{ISSN 0719-7160}

Note-se que não se deve imputar à Doutrina Católico o individualismo e o laicismo que podem desaguar do liberalismo político, uma vez que ela é ancorada na antropologia personalista, isto é, no reconhecimento de que o ser humano é pessoa, cuja dignidade individual é inviolável e vocacionado à comunhão, à integração comunitária e a participação no bem comum.

Dessa forma, o livre exercício da religião passou a ser reconhecido como direito fundamental na vasta maioria das Constituições ocidentais, e na brasileira, em particular, de 1988. O fundamento da liberdade religiosa é a sacralidade da consciência individual, elemento constitutivo da dignidade humana.

Trata-se de um aspecto inseparável da personalidade, sendo condição para a própria realização da pessoa enquanto ser humano. Nos termos da teoria da lei natural de John Finnis, que será explicada abaixo, a religião é um bem humano básico de cuja participação razoável depende o florescimento humano e o bem comum, sendo ambos os fundamentos da autoridade do Estado de Direito.

A abertura para a experiência com o sobrenatural, para uma realidade transcendente, é um elemento característico dos seres humanos, e a criação de embaraços a essa aspiração consistira em violência ilegítima que impediria o ser humano de alcançar o seu devido florescimento e a sua autorrealização. Cifuentes (1989, p. 185) sintetiza o argumento do seguinte modo:

$\mathrm{O}$ ato de fé, mais do que qualquer outro, é necessário que seja uma verdadeira autodeterminação. Eis porque, dum modo especialíssimo, o direito à liberdade religiosa é, em si, um direito natural absoluto, essencialmente unido à dignidade da pessoa humana.

O fato de ser um direito natural absoluto, aqui, não significa que esse direito não esteja articulado com outras prerrogativas jurídicas em sociedade e que não deva, portanto, ser equacionado com outros direitos igualmente fundamentais. A liberdade religiosa é um direito natural absoluto porque deriva diretamente da antropologia humana, do fato de cada indivíduo ser uma pessoa digna, dotada de autoconsciência e capaz de se abrir ao transcendente.

Esse direito não está submetido às convenções sociais e ás concessões políticas do Estado. Ao contrário, como direito natural, ele se opõe às coerções religiosas, aos impedimentos de exercício religioso e as obrigações de determinadas práticas religiosas compulsórias, que condicionariam o exercício de outros direitos de cidadania. 
Victor Sales Pinheiro \& Victor Cláudio Araújo Picanço Da Silva: A legitimidade constitucional do ensino religioso confessional em escolas públicas no Brasil: análise da ação direta de inconstitucionalidade 4.439 a partir da laicidade positiva em Bento XVI

Embora, esse reconhecimento da liberdade religiosa como direito fundamental tenha encerrado alguns desafios, o Ocidente ainda se debate sobre o alcance da laicidade estatal. Se antes as sociedades ocidentais compartilhavam internamente certa identidade ética de fundo cristão, como reconheceu Leão XIII na Encíclica Immortale Dei (VATICANO, 1885), no século XIX, no mundo hodierno, secularizado e plural, as identidades culturais e tradicionais parecem ter se dissolvido, ao mesmo tempo em que se multiplicaram diferentes concepções éticas, surgindo então a questão de como o Estado deve se portar ante essa nova configuração social pluralista sem comprometer o exercício da liberdade de religião.

A teoria do liberalismo político se volta exatamente para esse problema, que se agudizou no século XX. Almeida $(2008$, p. 27$)$ a sintetiza neste trecho de obra que trata especificamente do assunto deste Artigo, intitulado Liberalismo Político, Constitucionalismo e Democracia - A questão do ensino religioso nas escolas públicas, publicado em 2008, quase dez anos antes da decisão da Suprema Corte, em 2017, que resolveu a questão pela legitimidade constitucional do ensino público confessional:

Moldar o indivíduo a partir de valores compartilhados pela comunidade passou a ser insuficiente num ambiente de diversidade religiosa. A partir desse momento histórico, uma complexa relação entre diversidade cultural e igualdade começou a se desenvolver e a produzir uma nova base de legitimação de poder, fundada não mais na autoridade eclesiástica ou nas tradições culturais, mas num consenso abstrato e em constante tensão com as várias possibilidades de acomodação da diferença.

Esse excerto contém vários elementos importantes da teoria liberal, que devem ser anotados. Em primeiro lugar, a perda da unidade religiosa, que acima se mencionou a partir do Papa Leão XIII, é um fato consumado, que não pode ser negligenciado pela justiça política. Com efeito, o maior teórico liberal contemporâneo, John Rawls (1995, p. 57), toma "o fato do pluralismo" como um dos pressupostos centrais do seu pensamento, logo no início do seu último grande livro:

A diversidade de doutrinas compreensivas, religiosas, filosóficas e morais, que encontramos nas sociedades democráticas modernas, não constituem uma mera situação histórica que repentinamente poderá terminar; é uma característica permanente da cultura pública da democracia. Nas condições políticas e sociais que asseguram os direitos e as liberdades básicos de instituições livres, uma diversidade de doutrinas compreensivas opostas e inconciliáveis surgirá e persistirá, se é que tal diversidade já não está ocorrendo. (RAWLS, 1995, p. 57) 
A questão da diversidade cultural, oriunda da pluralidade das doutrinas compreensivas (ou abrangentes) instaura uma questão de igualdade: o Estado não pode beneficiar nenhuma delas, em detrimento de outras, daí a necessidade imperiosa de sua laicidade, ou neutralidade religiosa. 0 poder não se legitima, portanto, em qualquer autoridade eclesiástica, porventura obedecida pela maioria dos cidadãos, nem pela tradição cultural-religiosa que formou a nação, mas num consenso formal e abstrato, que está para além das diferenças substancias das visões de mundo, que garantiria a acomodação das diferenças. Em linhas muito gerais, assim pode ser sintetizado o problema da teoria liberal em relação à pluralismo ocasionado pela liberdade religiosa. Naturalmente, existem muitos outros conceitos relevantes para explicitá-la com mais profundidade, entretanto, delineiam-se apenas os elementos necessários para o argumento do Artigo.

\subsection{Laicidade e laicismo}

A acomodação de diferentes concepções religiosas na sociedade liberal secularizada se dá, principalmente, por meio da afirmação da laicidade, vista como condição para o exercício da liberdade religiosa ao impedir que o Estado adira a um credo em particular, privilegiando um setor da sociedade em detrimento de outros, uma vez que não há unidade religiosa de fundo, que já se chamou, acima, de o fato do pluralismo.

Associadas ao ideal do Estado de Bem-Estar Social do pós-II Guerra, as posições liberais ganharam relevo e avançaram na defesa de que o respeito à diversidade religiosa depende da contenção da religiosidade ao espaço público, para evitar que o Estado participasse de qualquer modo do proselitismo religioso. Segundo essa concepção extremada de liberalismo, o espaço público só seria verdadeiramente neutro se estivesse livre de qualquer manifestação religiosa, a qual deveria ser relegada ao âmbito da vida privada, sem qualquer exteriorização.

Para esta corrente do liberalismo político, recepcionada no Brasil pela obra de Almeida (2008, p. 32), a formação da vontade estatal não deve, sob nenhum pretexto, recorrer a crenças filosóficas ou religiosas de qualquer natureza, uma vez que se parte do pressuposto que nenhuma delas é aceita por todos os cidadãos de uma sociedade pluralista. A legitimação da política democrática deve se dar com base em "razões públicas", fruto de um acordo político obtido sem coação e sem pressupor nenhuma verdade moral ou religiosa prévia: 
Victor Sales Pinheiro \& Victor Cláudio Araújo Picanço Da Silva: A legitimidade constitucional do ensino religioso confessional em escolas públicas no Brasil: análise da ação direta de inconstitucionalidade 4.439 a partir da laicidade positiva em Bento XVI

uma concepção política de justiça é uma visão autossuficiente, ou seja, deriva de um ponto de vista político, aceito por todos e por isso capaz de permitir a estabilidade da vida social no contexto de pluralismo. A razão para essa autossuficiência é clara: se os membros da comunidade simplesmente não conseguem concordar com uma determinada doutrina metafísica abrangente, a concepção de justiça tem que partir de outra fonte, se pretende se afirmar com base normativa de um governo democrático estável (ALMEIDA, 2008, p. 32).

Para garantir a autossuficiência da concepção de justiça, restrita a elementos puramente políticos, a teoria liberal recorre ao conceito de razão pública. Ela seria radicalmente política, no sentido de não ter nenhum elemento metafísico ou religioso associado a ela, capaz de gerar dissenso na sociedade plural. Essa noção de razão pública é um elemento fundamental para a noção de estabilidade institucional de uma sociedade pluralista, pois alberga apenas critérios aceitáveis por todos, por motivos não abrangentes - morais metafísico ou religiosos.

A razão pública confere legitimidade e democracia à sociedade liberal, pois torna a obrigação jurídico-legal dependente do consenso de argumentos potencialmente aceitáveis por todos os cidadãos, e cujo fundamento é a própria Constituição (ALMEIDA, 2008, p. 122).

Torna-se, então, pertinente questionar qual seria o espaço atinente à religião na formação desta razão pública. Por que o Estado não deve levar em conta, em nenhuma hipótese, a contribuição da religião para a formação da "vontade" estatal? A razão religiosa não pode e apresentar na forma de uma razão pública, aceitável por todos os cidadãos?

Para enfrentar esses controversos questionamentos, é importante distinguir laicidade de laicismo. Qual a real distinção entre esses conceitos? Seriam apenas denominações diferentes sobre um mesmo fenômeno? Santamaría (2013, p. 12) sintetiza a oposição inicial entre os termos laicidade e laicismo:

Neste campo, há quem admita a laicidade e negue o laicismo como posição extrema ou extrapolada da laicidade. Há também os que distinguem entre laicidade em sentido positivo e laicidade em sentido negativo, admitindo a primeira e rejeitando a segunda: a positiva reconheceria a independência do poder civil, mas consideraria positivamente a religião; a segunda teria como propósito impedir qualquer poluição religiosa da ação política ou qualquer presença ou influência da religião - ou da experiência religiosa - no âmbito público.

Com feito, o sufixo "ismo" parece conferir ao termo "laicismo" um aspecto militante, agressivo. Seria, pois, uma abordagem antirreligiosa que busca afastar do espaço público qualquer 


\section{ISSN 0719-7160}

elemento transcendente. A religião não teria qualquer contribuição a fornecer à comunidade, sendo a sua exteriorização considerada nociva aos negócios do Estado e aos interesses da sociedade.

A manifestação da fé, sob este prisma, deveria se restringir ao foro íntimo de cada fiel e a atuação eclesial sofrer constante monitoramento, a fim de evitar a transposição dos limites considerados aceitáveis pelo Estado. Aqui, a religião é considerada um perigo, espécie de moléstia contagiosa, cabendo aos poderes públicos tão somente tolerar a sua existência e impedir que se "espalhe" a ponto de "contaminar" a formação da "vontade" estatal (PINHEIRO; SOUZA, 2016).

Neste contexto, o Poder Político encara a religião com preconceito e buscar "proteger" seus cidadãos da sua influência. Faz, assim, a opção de resguardar a identidade cívica nacional, extirpando do espaço público aqueles elementos de fé que poderiam servir para "manipular" a consciência do indivíduo. Isto se dá por meio de ações como a laicização do ensino, a retirada de símbolos religiosos dos prédios públicos, a proibição do uso ostensivo, ainda que pessoal, de itens característicos de determinado credo nas vias públicas, como crucifixos, véus etc. No contexto europeu, o principal exemplo desta abordagem hostil é a França (CATROGA, 2006, p. 229).

Ora, a laicização do ensino é exatamente o tema deste Artigo: não só que o ensino público não seja de matriz religiosa - por exemplo, dirigido por uma comunidade religiosa -, mas que não possa ministrar a disciplina de ensino religioso na sua dimensão confessional e propriamente religiosa. A alegação da PGR na ADI 4439 é a de que o ensino deveria ser laico e plural, sem confessar nenhum credo, no estilo de qualquer outra disciplina secular que enfoque o fenômeno religioso do ponto de vista das ciências humanas, como a História, a Sociologia, a Filosofia ou a Geografia.

Por sua vez, a laicidade consistiria na legítima separação entre o poder temporal e o poder espiritual, na qual o Estado não veria a religião como ameaça, mas como cooperadora para o bem comum, como argumenta Robert George (1999). Assim, a manifestação da fé dos cidadãos na arena pública não seria vista com desconfiança, mas como fato positivo e que merece ser incentivado. O caso dos EUA, pela relação "amigável" entre o Estado americano e as religiões, seria o paradigma desta abordagem, ainda segundo Catroga (2006, p. 146), que compara o laicismo francês com a laicidade norte-americana.

Ademais, deve-se salientar que a laicidade protege tanto os cidadãos religiosos quanto os seculares, voltando-se contra aqueles que consideram o elemento religioso com suspeita. Ou seja, a 
Victor Sales Pinheiro \& Victor Cláudio Araújo Picanço Da Silva: A legitimidade constitucional do ensino religioso confessional em escolas públicas no Brasil: análise da ação direta de inconstitucionalidade 4.439 a partir da laicidade positiva em Bento XVI

laicidade defende não só a neutralidade de Estado em matéria religiosa, mas também se defende do anticlericalismo de quem promove "um revolução cultural militantemente apostada no enraizamento dos direitos de cidadania." (CATROGA, 2006, p. 297). Não se deve confundir, portanto, a laicidade com o espírito anticlerical, secularista ou antirreligioso, sendo tais características típicas da postura laicista.

Essa distinção entre laicidade (conotação positiva) e laicismo (conotação negativa) é majoritária entre os estudiosos do tema que, no contexto do pensamento católico contemporâneo, seguem o Magistério do Concílio Vaticano II e de Bento XVI, como Perea (2012), Guarrido (2011), Luño (2007), Fazio (2012b), Cartabia e Simonci (2013), Contreras (2013), Rhonheimer (2013), George (1999) e Finnis (2011).

Contudo, essa distinção não é unânime, impondo-se mencionar, por força da dialética que rege um argumento filosófico robusto, pelo menos duas importantes vozes divergentes, a Miguel Ayuso e a de Bernard Dumont. Não se aprofundam os seus argumentos, por limitação metodológica deste Artigo, mas registra-se que eles merecem atenção (DIP, 2017; BRODEBECK, 2016).

Para Miguel Ayuso (2008), além de não serem conceitos opostos, na verdade, laicidade e laicismo são termos pertencentes ao mesmo espectro ideológico antirreligioso, que se complementam. O laicismo seria agressivo, ao passo que a laicidade, respeitosa, mas ambos advogam a separação entre Igreja e Estado, rechaçando o Estado Católico, baseado na união deles, ainda que reconheça a distinção - mas não a separação - entre poder espiritual e poder temporal. Assim, laicismo e laicidade seriam duas posturas, uma mais rígida e outra mais flexível ou tolerante, que visariam o mesmo fim: manter a esfera pública alheia à influência religiosa.

Na mesma esteira, Bernard Dumont (2008, p. 495) esclarece que o laicismo é uma estratégia utilizada para se alcançar e se manter a laicidade do Estado. Desta forma, a laicidade seria o ideal a buscar e o laicismo, o meio, a arma utilizada para se concretizar a neutralidade estatal em matéria religiosa: "a ortodoxia ou a normalidade da laicidade é o laicismo. E o laicismo, podemos defini-lo, como o instrumento político da ateização do espaço público."

Logo, ainda que o Estado guardasse uma postura do tipo "amigável", como a citada anteriormente, velaria para que a influência da religião não se tornasse hegemônica, a ponto de "afetar" a neutralidade estatal. Para isso se utilizaria de instrumentos "laicizadores", impedindo o livre exercício da religião e, em última instância, não aceitando a sua autoridade moral, como defensora da lei natural (MENOZZI, 2012; HOLLENBACH, 2014; MACHADO, 2013). 


\section{A LAICIDADE POSITIVA EM BENTO XVI}

Qual é a posição da Igreja Católica nesse debate entre laicidade e laicismo? Ela reconhece a laicidade como uma conquista cristã, que dessacralizou a religião civil pagã? $E$, mais especificamente, qual é o Magistério do Papa Emérito Bento XVI em matéria de liberdade religiosa? Enfrentam-se essas questões nesta seção, a partir do horizonte do problema delineado na seção anterior (FAZIO, 2010).

Como anunciado desde a Introdução, o objetivo deste trabalho é demonstrar: (1) que a resposta da Igreja ao desafio da secularização foi a edificação do conceito de "laicidade positiva", também chamada de "sã laicidade", que reivindica a presença da religião no espaço público e destaca a sua atitude de colaboração com o Estado; e (2) como se desenvolveu esse importante conceito no Pontificado de Bento XVI. Para isso, será analisada a abordagem que o Pontífice conferiu ao tema nos seus pronunciamentos e nas manifestações oficiais da Santa Sé.

\subsection{Pluralismo, liberdade religiosa e laicidade}

O contexto enfrentado pela Igreja do século XXI e que é encontrado por Joseph Ratzinger em 2005, quando assume o trono pontifício, é bem descrito pelo Arcebispo Giovanni Lajolo, em discurso proferido por ocasião da conferência “Liberdade Religiosa, Alicerce da Dignidade Humana" em março de 2004 (VATICANO, 2004a).

Nele, o então Secretário para a Relação da Santa Sé com os Estados aponta os desafios contemporâneos relativos à liberdade religiosa, entre os quais está o reconhecimento pelos Estados da dimensão pública da religião e de sua capacidade de cooperar para o bem comum.

Com efeito, a preocupação da Santa Sé volta-se ao crescimento de um secularismo agressivo que alimenta formas de intolerância à presença do elemento religioso no espaço público. Segundo Santamaría (2013, p. 12), este ambiente hostil, laicista rechaça de pronto qualquer influência da religião no espaço público, como se qualquer gesto cristão na política fosse "uma ilegítima intromissão na vida pública e um regresso a épocas pretéritas, em que o poder religioso as igrejas cristãs e especialmente a Igreja Católica - teria sido dono de almas e terras, e teria condicionado de maneira abusiva e ilegítima a ação política." 
Victor Sales Pinheiro \& Victor Cláudio Araújo Picanço Da Silva: A legitimidade constitucional do ensino religioso confessional em escolas públicas no Brasil: análise da ação direta de inconstitucionalidade 4.439 a partir da laicidade positiva em Bento XVI

No mesmo sentido, em discurso durante a 60a Sessão da Comissão de Direitos Humanos da ONU, ocorrida em 2004, Monsenhor Silvano Maria Tomasi, declarou que "um modo sutil e crescente de intolerância religiosa é se opor ao direito da religião de se posicionar publicamente sobre assuntos relativos a formas de comportamento que são consideradas contrárias a princípios de natureza moral e religiosa." (VATICANO, 2008b).

Em meio às polêmicas em torno da questão, a Igreja, pode-se dizer, oficializou a opção pela compreensão de laicidade e laicismo como conceitos não apenas distintos, mas como fenômenos opostos. Segundo o Compêndio da Doutrina Social da Igreja (VATICANO, 2004b):

$\S 572$. O princípio da laicidade comporta o respeito de toda confissão religiosa por parte do Estado, "que assegura o livre exercício das atividades cultuais, espirituais, culturais e caritativas das comunidades dos crentes. Numa sociedade pluralista, a laicidade é um lugar de comunicação entre as diferentes tradições espirituais e a nação». Infelizmente permanecem ainda, inclusive nas sociedades democráticas, expressões de laicismo intolerante, que hostilizam qualquer forma de relevância política e cultural da fé, procurando desqualificar o empenho social e político dos cristãos porque se reconhecem nas verdades ensinadas pela Igreja e obedecem ao dever moral de ser coerentes com a própria consciência... (grifo nosso)

Esse trecho sintetiza o teor do magistério conciliar, cuja continuidade hermenêutica com a Tradição da Igreja é sempre ressaltada por Bento XVI (SARTO, 2011). Nele, percebem-se, claramente, um equilíbrio dialético entre o pluralismo democrático, pautado no princípio da laicidade do Estado, que permite "a comunicação entre as diferentes tradições espirituais e a nação", e, por outro lado, o reconhecimento das "verdades ensinadas pela Igreja".

O Magistério da Igreja reconhece não só o "fato do pluralismo", que serve de premissa fática do liberalismo político de Rawls (1995), mas a necessidade de um espaço laico religiosamente neutro - da esfera pública, para que possa haver o diálogo e a comunicação entre as diferentes tradições religiosas. Ao mesmo tempo, incentiva os cristãos a valerem-se da laicidade da esfera pública exatamente para participarem ativamente dela, seguindo à sua consciência e as verdades morais que a Igreja anuncia, e a que eles aderem e defendem livremente. Naturalmente, - gozo da liberdade de religiosa implica a reciprocidade política de permitir que outras manifestações religiosas tenham o seu espaço público garantido (RATZINGER, 2007, p.9-232).

Ou seja, articula-se as noções de liberdade, que gera um pluralismo religioso, moral e cultural, e a verdade única de Cristo, de que a Igreja é a depositária e anunciadora. Pode-se lembrar, desde logo, do título de uma das Encíclicas mais importantes do Papa Bento XVI, Caritas in Veritate: não se pode divorciar a caridade da verdade, sob o risco de recair seja num moralismo 
ISSN 0719-7160

sem fundamento metafísico, seja num dogmatismo sem dimensão moral (ROWLAND, 2013, p. 101$122 ; 149-170)$.

Ademais, esse excerto sublinha o "laicismo intolerante", que se manifesta na indisposição ao diálogo de qualquer conteúdo religioso, como se ele estivesse a priori errado, pelo simples fato de proceder da Revelação cristã. Trata-se de uma hostilidade que menospreza e subestima a "relevância política e cultural da fé", desqualificando a atuação social e política dos cristãos como fundamentalista, extremista e obscurantista.

A Igreja Católica reivindica participar, de modo particular por meio dos seus fiéis leigos, da esfera pública da sociedade porque sabe as verdades da fé contribuem, objetivamente, para a formação humana integral. Sem ela, o ambiente cultural em geral fica empobrecido, impedindo o homem do seu desenvolvimento em busca de Deus, pelas ideologias do materialismo, ateísmo e hedonismo. Como diz Bento XVI na referida Encíclica Caritas in Veritate:

A exclusão da religião do âmbito público e, na vertente oposta, o fundamentalismo religioso impedem o encontro entre as pessoas e a sua colaboração para a para o progresso da humanidade. A vida pública torna-se pobre de motivações, e a política assume um rosto oprimente e agressivo. Os direitos humanos correm o risco de não ser respeitados, ou porque ficam privados do seu fundamento transcendente ou porque não é reconhecida a liberdade pessoal. (VATICANO, 2009)

Nessa importante passagem da Encíclia, o papa pontua elementos essenciais do seu Magistério sobre a laicidade, que interessa a este Artigo: a possibilidade de dois tipos de exclusão da religião do espaço público, a lacista (exclusão de toda religião da esfera política) e a fundamentalista (absolutização de uma única religião oficial). Com essa modalidade radicalmente empobrecida de sociabilidade humana, a perda é universal, para toda a sociedade, que se vê privada da fonte transcendente de sentido da existência, que só a religião fornece. Apostando na Verdade de Cristo, a Igreja participa do diálogo público a fim de anunciá-Lo, consciente de que esse proselitismo é benfazejo a todos. A vida pública, sem a religião, se torna individualista, rivalitária e revanchista. Os direitos humanos, por sua vez, desvinculados da sua dimensão antropológica, relativa à natureza huamana, e teológica, concernente à essência criatural do homem, esvaziam-se num convencionalismo relativista. Esses são pontos relevantes do horizonte ratzingeriano que se descortina nesta seção. 
Victor Sales Pinheiro \& Victor Cláudio Araújo Picanço Da Silva: A legitimidade constitucional do ensino religioso confessional em escolas públicas no Brasil: análise da ação direta de inconstitucionalidade 4.439 a partir da laicidade positiva em Bento XVI

\subsection{Gradações da laicidade: o equilíbrio cristão entre laicismo e fundamentalismo}

A caracterização delineada até aqui ainda não é suficiente para abranger toda a problemática contemporânea das relações entre Igreja e Estado. Prova disso é que, em seus pronunciamentos, Bento XVI manejou os conceitos de forma inconstante, utilizando ora o termo "laicidade" como sinônimo de laicismo, ora como concepção oposta (BASSET, 2010). Nesses ensaios de conceituação, o Papa busca se equilibrar entre os extremos do laicismo secularista (de matriz agnóstica ou ateísta) e do fundamentalismo teocrático (de matriz islâmica).

Na entrevista aos jornalistas responsáveis pela cobertura da sua viagem à Turquia, no ano de 2006, o Pontífice definiu o laicismo como a posição de confronto do Estado com as organizações religiosas, em oposição à noção da laicidade. Nesse sentido, o laicismo separa "totalmente a vida pública de qualquer valor das tradições", ao passo que a laicidade "realça e preserva a verdadeira diferença e autonomia entre as esferas [política e religiosa], mas também a sua coexistência, a responsabilidade comum." (VATICANO, 2006a)

A intenção do Sumo Pontífice, nessa entrevista, é sublinhar a harmonia e mesmo a "fecundação recíproca" dos âmbitos político e religioso, pela "base de valores que têm fundamentalmente uma origem comum" (VATICANO, 2006a).

Contudo, posteriormente, na sua Exortação Apostólica Ecclesia in Medio Oriente, essa distinção foi obscurecida. A "laicidade", em sua gradação mais radical, torna-se sinônimo de laicismo, modo tão intolerante e extremista quanto o fundamentalismo de relacionamento entre Estado e religião (VATICANO, 2012):

Duas novas realidades

29. O Médio Oriente, como aliás o resto do mundo, conhece duas realidades opostas: a laicidade com as suas formas por vezes extremas [laicismo] e o fundamentalismo violento que reivindica uma origem religiosa. Determinados responsáveis políticos e religiosos do Médio Oriente, presentes nas diversas comunidades, olham com grande suspeita para a laicidade considerando-a ateia ou imoral. É verdade que às vezes se ouve esta afirmar, de maneira redutora, que a religião diz respeito exclusivamente à esfera privada, como se não passasse de um culto ao nível individual e familiar, situado fora da vida, da ética e da relação com os outros. Na sua forma extrema e ideológica, esta laicidade torna-se secularismo negando ao cidadão a expressão pública da sua religião e pretendendo que o Estado seja o único a poder legislar sobre a forma pública da mesma. Estas teorias são velhas; já não estão circunscritas ao Ocidente, nem se podem confundir com o cristianismo. (grifo nosso) 
Note-se que Bento XVI busca, mais uma vez, ressaltar o equilíbrio do cristianismo entre os extremos do laicismo e do fundamentalismo (FINNIS, 2015, p. 95-96). Ambas as posturas negam o direito fundamental à liberdade religiosa, seja porque neutraliza o espaço laico da esfera pública em que a pluralidade das religiões se manifesta com total desembaraço, tornando-a absolutamente infensa a todo tipo de religião, no caso do laicismo, seja porque torna a esfera pública absolutamente religiosa, sem qualquer dimensão de laicidade que permita a convivência com a alteridade religiosa.

Também é importante notar a associação imediata dessa laicidade extremada, a qual, na distinção conceitual aqui elaborada se deve chamar de laicismo, com o ateísmo ou imoralismo. Na verdade, como demonstra Jónatas Machado, o Estado Constitucional, que respeita a liberdade religiosa como um direito humano fundamental e alienável, é pautado nos princípios cristãos teístas da dignidade da pessoa humana, da racionalidade e da consciência moral, da igualdade, solidariedade e justiça social e, exatamente, da separação das confissões religiosas do Estado (MACHADO, 2013, p. 29).

Na mesma ocasião, o Pontífice percebeu a necessidade de qualificar o tipo de laicidade admitido pela Igreja, separando-a das formas "extremadas que a degeneram em laicismo". Para isso, foi utilizado o adjetivo "sã", explicitando com qual laicidade a Igreja se identifica: "a sã laicidade significa libertar a religião do peso da política e enriquecer a política com o contributo da religião, mantendo entre ambas a distância necessária, a distinção clara e a colaboração indispensável." (VATICANO, 2012)

O Papa explica que "nenhuma sociedade pode desenvolver-se, de maneira sadia, sem defender o mútuo respeito entre política e religião, evitando a tentação constante de se misturarem ou contraporem." (VATICANO, 2012) Mas em que se funda esta distinção? E por que se mantê-la bem definida?

Na linha de seu antecessor, Papa João Paulo II, Bento XVI reconduz a questão teológicopolítica à realidade antropológica que sempre está pressuposta em qualquer debate social (CINQUINA, 2010). Para que a laicidade seja "sã", a antropologia deve ser "reta". Criado à imagem e semelhança de Deus, a pessoa humana é dotada de uma dignidade ontológica inalienável, sujeita a direitos humanos fundamentais, como a da liberdade religiosa, isto é, o direito de não ser coagido em matéria de crença, sob o risco de violar a sua consciência. 
Victor Sales Pinheiro \& Victor Cláudio Araújo Picanço Da Silva: A legitimidade constitucional do ensino religioso confessional em escolas públicas no Brasil: análise da ação direta de inconstitucionalidade 4.439 a partir da laicidade positiva em Bento XVI

Não se trata, porém, de separar o âmbito político do religioso, mas de distingui-los e fazêlos cooperar pelo bem comum, que é finalidade de ambos, embora, para a religião, o bem comum político tenha o aspecto instrumental de franquear os meios de consecução da salvação eterna. Nesse sentido, a política não tem, prima facie, finalidade religiosa de promover a redenção do gênero humano, cabendo este à Igreja (FINNIS, 1998, p. 320).

Nesse contexto de interdependência, o Papa se refere a uma "justa relação" de unidadedistinção". Unidade, porque ambos cooperam para o bem comum; distinção, porque não se confundem, nem pela origem da autoridade, nem pelos meios empregados. Só assim, com base nesse princípio de laicidade sã, a política não instrumentaliza a religião, que pode se inserir livremente na vida social, sem tampouco dogmatizar e encerrar o espaço público nos seus dogmas revelados. Essa unidade-distinção é indispensável para ambas: sem a outra, cada uma perde sua identidade específica e tende a se absolutizar, como nas formas históricas do cesaropapismo e do papocesarismo (BENTO; ROSA; DOMINGUES; 2019).

Se Bento XVI reconduziu o problema à questão antropológica, também o articulou com a dimensão pedagógica, reclamando uma "adequada formação humana e religiosa", que garanta, "paciente e corajosamente", a consecução desta justa e tensa relação entre política e religião: "É preciso não esquecer jamais o lugar de Deus na vida pessoal, familiar e social, nem o lugar do homem no desígnio de Deus; e, sobretudo, é preciso rezar mais para o conseguir" (VATICANO, 2012).

Essa laicidade saudável - em contraste a uma laicidade doente, porque aniquila o caráter transcendente do homem - dá um passo adiante em relação à distinção "oficializada" no Compêndio previamente citado, instituindo nas relações entre Igreja e Estado uma necessária colaboração ativa, a fim de alcançar o bem comum da sociedade (VATICANO, 2006b).

Cabe destacar, todavia, que a expressão "sã laicidade" já havia sido utilizada por Pio XII, décadas antes. Bento XVI, buscando acentuar o aspecto "positivo" da religião no espaço público, acrescenta este adjetivo, uma vez que a sanidade da laicidade não é só o fato de não politizar a religião ou divinizar a política, mas se refere à dimensão objetivamente positiva da religião no espaço político.

\subsection{Laicidade positiva, formação humana integral e a educação religiosa}




\title{
ISSN 0719-7160
}

Assim, a originalidade do termo "laicidade positiva" consiste na sua dupla acepção: (1) a valoração moral das contribuições oferecidas pela religião à sociedade como algo bom, e (2) a própria exteriorização da ação religiosa, em si mesma.

A mesma preocupação é reiterada por Bento XVI em sua importante encíclica social Caritas in Veritate, quando equipara esta atitude laicista ao fundamentalismo religioso:

\begin{abstract}
Mas há que acrescentar que, se o fanatismo religioso impede em alguns contextos o exercício do direito de liberdade de religião, também a promoção programada da indiferença religiosa ou do ateísmo prático por parte de muitos países contrasta com as necessidades do desenvolvimento dos povos, subtraindo-Ihes recursos espirituais e humanos. (...) Quando o Estado promove, ensina ou até impõe formas de ateísmo prático, tira aos seus cidadãos a força moral e espiritual indispensável para se empenhar no desenvolvimento humano integral e impede-os de avançarem com renovado dinamismo no próprio compromisso de uma resposta humana mais generosa ao amor divino. (VATICANO, 2009)
\end{abstract}

Este excerto é muito significativo para o argumento deste Artigo, pois o ensino laico de religiões, proposto pela PGR para substituir o ensino religioso confessional nas escolas públicas, subentende uma "promoção programada da indiferença religiosa ou do ateísmo prático", uma vez que nivela todas as diferenças religiosas essenciais, reduzindo todas as religiões a meras manifestações antropológicas e culturais. Nesse caso, não haveria nenhuma distinção entre religião e cultura, restando ociosa a distinção que a própria Constituição Federal Brasileira realiza entre elas.

Aqui, o Papa equaciona o fanatismo religioso de sociedades políticas que privam o direito de liberdade de religião, ao impor uma forma exclusiva de credo religioso, com direta ingerência no sistema de ensino e na difusão da cultura em geral, com o ateísmo prático das sociedades dita liberais que neutralizam todo alcance público e social da religião, sobretudo pela doutrinação no sistema educacional.

Acredita-se que o caso jurídico que inspira essas reflexões se insere exatamente nesse contexto, no de neutralização da religião no espaço público da escola, que deve promover a formação integral do aluno, inclusive na dimensão propriamente religiosa.

Como se explica na próxima seção, não se deve confundir o ensino religioso confessional (no singular) com o ensino laico de religiões (no plural). O primeiro é uma participação de um credo específico, a partir da compreensão da sua dimensão racional. Ou seja, é a prática religiosa 
Victor Sales Pinheiro \& Victor Cláudio Araújo Picanço Da Silva: A legitimidade constitucional do ensino religioso confessional em escolas públicas no Brasil: análise da ação direta de inconstitucionalidade 4.439 a partir da laicidade positiva em Bento XVI

propriamente dita, que compõe, além da dimensão doutrinal-intelectual, uma dimensão exterior ritual-litúrgica, uma dimensão interior de piedade espiritual e uma dimensão moral-social.

O segundo caso, proposto pela PGR, de um ensino laico de religiões, pressupõe o relativismo cultural e o imanentismo religioso, gerando um indiferentismo religioso, pois de antemão acredita que todas as religiões se equivalem, que são todas produções culturais de sociedades históricas, com simbolizações de experiências particulares. Do ponto de vista epistemológico, subjazem as ciências da religião, pautadas sobretudo na Antropologia e Sociologia. Isto é, a Teologia, que a Ciência cujos pressupostos são os dados da Revelação, não é abordada na sua dimensão apologética, tanto de teologia fundamental, como explicitação das bases epistemológicas do conhecimento teológico, que articula fé e razão, quanto de defesa da fé no diálogo com outras tradições.

Se o Estado colabora com a Igreja na realização do bem comum, cujo conteúdo é a participação dos bens humanos pelos cidadãos em geral, como ele pode neutralizar a religião justamente pelo ensino laico que a desmistifica?

Frente a ameaças laicistas como essa, Bento XVI utiliza os termos "sã laicidade" e "laicidade positiva" em carta dirigida ao então presidente do Senado italiano, Marcelo Pera, em defesa de que todos os cidadãos vivam, com autêntica liberdade, a sua fé no espaço público, sem discriminação, ressaltando a "relevância primordial" de salvaguardar "aquele 'senso religioso' no qual se exprime a abertura do ser humano à Transcendência. Um Estado adepto da sã laicidade deverá logicamente conferir espaço em sua legislação também a esta dimensão fundamental da alma humana." (VATICANO, 2005).

No caso jurídico estudado neste Artigo, é facultado a alunos religiosos terem acesso ao ensino religioso confessional, sem prejuízo das demais disciplinas científicas ministradas, e sem detrimento, também, dos alunos que não queiram praticar a religião, ou que tenham outra religião. Na não obrigatoriedade do ensino religioso repousa a liberdade religiosa, tanto na sua dimensão negativa, de o cidadão não ser coagido na sua consciência religiosa, quanto positiva, de lhe ser ofertado o ensino religioso, para que ele possa, objetivamente, realizá-lo, caso queira (WEIMGARTEN, 2015).

Ancorada na antropologia personalista, que reconhece as faculdades sociais, racionais e intelectuais de cada pessoa, a "formação humana integral" a que se refere o Pontífice na Encíclica Caritas in Veritate, pressupõe a abertura ao transcendente, o contato com Deus. Por isso, uma 
ISSN 0719-7160

escola pública que coopere com o bem comum deve oferecer, facultativamente, aos seus alunos essa possibilidade, que não fere, antes promove a liberdade religiosa dos alunos.

\subsection{O papel positivo da religião no espaço público de Turquia, Estados Unidos, França e Brasil}

Percebe-se que a abordagem positiva da laicidade não se restringe à garantia de o indivíduo manifestar a sua fé no âmbito privado, mas também alcança o cidadão cabe o direito expressar a sua religiosidade também no espaço público e, motivado por ela, influenciar as decisões políticas.

Ao longo de seu Pontificado (2005-2013), a doutrina da laicidade positiva aperfeiçoa-se também nos pronunciamentos de Bento XVI e nas manifestações da Santa Sé, nas relações diplomáticas com países importantes do cenário mundial, marcados pelo pluralismo. Antes de chegar ao Brasil e verificar se o ensino religioso confessional em escola pública fere a laicidade estatal, tal como alegado pelo PGR na ADI 4439, convém acompanhar a explicitação do argumento pontifical nas falas do Pontífice Romano em países como a Turquia, Estados Unidos da América (ONU) e França.

Ao visitar a Turquia, país de maioria muçulmana, havia bastante tensão pelo incidente, ocorrido poucos meses antes, do discurso pronunciado pelo Papa na Universidade de Ratisbona, em que citou palavras críticas a Maomé e ao uso da violência para a expansão do islã (VATICANO, 2006c), gerando bastante polêmica e uma crise diplomática com países de maioria islâmica.

No discurso junto ao corpo diplomático turco, Bento XVI teceu elogios ao regime de laicidade vigente naquele país e defendeu a valorização da atuação das religiões na sociedade: reconhecer o pluralismo religioso, respeitar o direito a não ser coagido em matéria religiosa, é honrar a dignidade da consciência individual, permitindo contemplar, mais claramente, a antropologia da pessoa humana, criada à imagem e semelhança de Deus. Quanto mais se posiciona a pessoa humana no centro da ação política, econômica, cultural e social, tanto mais se celebra a sua dignidade, capaz de aceder a Deus e a pacificar a sociedade. (VATICANO, 2006b)

Na mesma viagem, em discurso ao Presidente para Assuntos Religiosos da Turquia, afirmou que a liberdade de exercício da religião é condição necessária para que os crentes possam contribuir com a sociedade, destacando a dimensão pública da fé. Para tanto, faz-se necessário resguardar a liberdade de religião, "institucionalmente garantida e efectivamente respeitada", 
Victor Sales Pinheiro \& Victor Cláudio Araújo Picanço Da Silva: A legitimidade constitucional do ensino religioso confessional em escolas públicas no Brasil: análise da ação direta de inconstitucionalidade 4.439 a partir da laicidade positiva em Bento XVI

tanto aos indivíduos quanto às comunidades. Só assim, os crentes podem contribuir para a edificação da sociedade, consoante o gesto tipicamente cristão de serviço, sobretudo em relação aos mais vulneráveis e pobres (VATICANO, 2006d).

O Sumo Pontífice se refere às inúmeras obras de caridade que a Igreja presta à sociedade em geral, que contribuem diretamente ao bem comum, relativas à saúde, educação e cultura (WOODS JR., 2011). Como podem os cristãos atuar na esfera pública deixando se ser eles mesmos, de manifestar suas crenças?

Pouco depois, referindo-se à mesma viagem, desta vez em Audiência Geral, na data de 06 de dezembro de 2008, o Papa voltou a enaltecer a laicidade turca, que valoriza a dimensão pública da religião ao mesmo tempo em que preserva o Estado do fanatismo religioso. A virtude deste país incrustado entre a Ásia e a Europa, de tão conturbada história entre o cristianismo e o islamismo, é regulada por uma Constituição moderna que afirma a laicidade do Estado, mesmo com uma vastíssima maioria mulçumana.

É um país digno de nota pois logra equilibrar-se entre os extremos do laicismo e do fundamentalismo, uma vez que permite a expressão pública da religião - necessária para a redescoberta da realidade objetiva de Deus -, sem recair nas violentas degenerações fundamentalistas (VATICANO, 2006b).

Em abril de 2008, por ocasião da viagem aos Estados Unidos da América e à Organização das Nações Unidas, Bento XVI insistiu no tema da laicidade, liberdade religiosa e necessidade de se garantir aos fiéis o direito de expressar publicamente a sua fé. Nesse sentido, é oportuno destacar seu discurso por ocasião do Encontro com Membros da Assembleia Geral das Nações Unidas (VATICANO, 2008a):

Por isso é inconcebível que crentes devam suprimir uma parte de si mesmos a sua fé para serem cidadãos activos; nunca deveria ser necessário renegar Deus para poder gozar dos próprios direitos. Os direitos relacionados com a religião necessitam como nunca de serem protegidos se forem considerados em conflito com a ideologia secular prevalecente ou com posições de uma maioria religiosa de natureza exclusiva. Não se pode limitar a plena garantia da liberdade religiosa à prática livre de culto; ao contrário, deve ser tida em justa consideração a dimensão pública da religião e portanto a possibilidade dos crentes desempenharem a sua parte na construção da ordem social.

Aqui, percebe-se que a ideologia secular do lacisimo pretende enclausurar os cidadãos na esfera privada, reduzindo consideravelmente a sua liberdade religiosa de atuarem na esfera 


\section{ISSN 0719-7160}

pública. Ademais, na linha do raciocínio de John Finnis (2011) ao criticar a noção excludente da razão pública liberal de John Rawls (PINHEIRO; NEIVA, 2019), Bento XVI afirma a unidade da personalidade humana, que não pode se fragmentar e elidir a dimensão religiosa da sua identidade ao participar da esfera pública, renegado Deus para gozarem de certos direitos.

A razão prática é uma e não pode ser fragmentar ao aturar no âmbito político. Quem é de fato religioso, nunca deixa de sê-lo, não pode suspender essa condição em determinado momento. Ao contrário, trata-se da realidade mais inexorável e inalienável de sua existência, pois é um estado compreensivo que abrange todos os âmbitos do seu ser.

Percebe-se aqui também alguma ressonância do debate de Ratzinger, à época ainda Cardeal, com o filósofo secular Habermas, promovido pela Academia Católica de Baviera, em Munique, em 2004. Nele, Habermas reconhece que o espaço público liberal e laico deve acolher os cidadãos crentes, em par de igualdade com todos os outros cidadãos, uma vez que muitos religiosos participam do debate público exatamente por causa da sua convicção teológica. Não há qualquer sentido um Estado que se diz liberal impedir a participação dos cidadãos religiosos, que podem e devem participar do processo democrático com toda a liberdade e igualdade que é destinada aos demais concidadãos, resguardando a solidariedade social e jurídica (HABERMAS; RATZINGER, 2007).

No pronunciamento que Bento XVI proferiu na Audiência Geral de 30 de abril de 2008 (VATICANO, 2008c), ao relatar o diálogo que manteve com o presidente norte-americano, reafirmou a defesa da sã laicidade como modelo a ser promovido, ressaltando a

feliz união entre princípios religiosos, éticos e políticos, e que ainda hoje constitui um válido exemplo de sadia laicidade, onde a dimensão religiosa, na diversidade das suas expressões, é não só tolerada, mas valorizada como "alma" da Nação e garantia fundamental dos direitos e dos deveres do homem.

A dimensão pública da religião, tão reclamada por Bento XVI, pode ser compreendida também como uma contribuição que os crentes são levados a oferecer à sociedade. Este comprometimento social é exigido pela própria vivência da fé, constituindo-se parte integrante do exercício da religião. Isto é, pode-se dizer que faz parte da prática religiosa, especialmente a católica, a preocupação com o bem comum e a disposição do fiel de se colocar voluntariamente à serviço da comunidade. Assim, um Estado que não admitisse a participação de um fiel na formação 
Victor Sales Pinheiro \& Victor Cláudio Araújo Picanço Da Silva: A legitimidade constitucional do ensino religioso confessional em escolas públicas no Brasil: análise da ação direta de inconstitucionalidade 4.439 a partir da laicidade positiva em Bento XVI

da vontade pública, estaria cometendo uma grave violação ao livre exercício da religião (VATICANO, 2008c).

De todos os pronunciamentos relativos à questão da laicidade, certamente, o mais paradigmático foi o discurso às autoridades francesas, na oportunidade da viagem apostólica àquele país, em 2008. Isso se deve ao fato de a França ser considerada o berço do laicismo, cujo retrato mais emblemático foi a agressiva lei de separação entre Igreja e Estado, instituída em 1905, que representou grave ataque à liberdade da Igreja naquele país.

Bento XVI parece conformar-se à compreensão defendida pelo então presidente da França, Nicolas Sarkozy, sobre a "laicidade positiva", e que, por todo o simbolismo envolvido, foi uma das razões que fez a expressão ganhar notoriedade:

De facto, é fundamental, por um lado, insistir sobre a distinção entre o âmbito político e o religioso, para tutelar quer a liberdade religiosa dos cidadãos quer a responsabilidade do Estado em relação a eles, e, por outro, consciencializar-se mais claramente da função insubstituível da religião na formação das consciências e da contribuição que a mesma pode dar, juntamente com outras instâncias, para a criação de um consenso ético fundamental na sociedade. (VATICANO, 2008c)

Com efeito, o conteúdo desta "laicidade positiva" a que Bento XVI adere havia sido delineado pelo presidente francês em visita ao Vaticano, em dezembro de 2007, na Basílica Papal de São João de Latrão (ALLEN JR., 2008).

Neste discurso significativo, Sarkozy reconhece a importância que a consciência dos agentes públicos sejam "iluminadas por opiniões que fazem referência a normas e convicções que residem para além das contingências imediatas". Ou seja, percebe que a consciência moral de fundamento religioso auxilia na consecução do trabalho político, tão desafiador por exigir a gestão de uma pluralidade incomensurável de credos. Por isso, a sabedoria religiosa apresenta a transcendência e a universalidade como categorias aptas a articula as "contingências imediatas" do cotidiano político num quadro mais amplo de sentido e abrangência, consoante a tradição religiosa.

Ademais, Sarkozy saúda a "sã laicidade" de Bento XVI, como "uma laicidade que, ao mesmo tempo em que protege a liberdade de pensamento, a liberdade de crer ou não crer, não considera as religiões um perigo, mas, em vez disso, algo positivo." (ALLEN JR., 2008)

Ao tratar da questão ambiental em discurso aos representantes diplomáticos dos países junto à Santa Sé (VATICANO, 2010), o Papa Bento XVI reconhece que esse complexo problema exige esforços redobrados na educação, porque se trata de uma questão eminentemente moral, que 


\section{ISSN 0719-7160}

exige "promover uma real mudança das mentalidades e estabelecer novos modos de vida." Para tanto, urge superar o laicismo que hostiliza os cristãos na esfera pública, gerando conflito e desunião social, que impossibilita a resolução do dilema ambiental. Este exige, ao contrário, "um espírito de responsabilidade compartilhada", que seja inclusivo com todos os cidadãos, conforme o pluralismo da "laicidade positiva, aberta, que, fundada sobre uma justa autonomia da ordem temporal e da ordem espiritual, favoreça uma sã cooperação..." (VATICANO, 2010).

Como se observa, na oportunidade, o Pontífice colocou em relevo a participação dos crentes no estabelecimento de políticas relativas ao meio ambiente e reivindicou a adoção do regime da "laicidade positiva" como instrumento mais adequado e receptivo a esta colaboração dos fiéis.

O conceito, da forma como foi desenvolvido, significando o respeito e a abertura que o Estado deve dar à expressão religiosa no espaço público, favorecendo a sua presença e a participação dos fiéis, foi assimilado à doutrina político-social da Igreja, norteando as suas iniciativas nas relações com os Estados.

O exemplo mais significativo dessa doutrina se encontra no Acordo firmado entre República brasileira e a Santa Sé (BRASIL, 2010), que formalizou o Estatuto Jurídico da Igreja Católica no Brasil, e que demonstra, perfeitamente, o conceito de laicidade positiva no tocante ao ensino religioso:

Artigo 2ㅇ - A República Federativa do Brasil, com fundamento no direito de liberdade religiosa, reconhece à Igreja Católica o direito de desempenhar a sua missão apostólica, garantindo o exercício público de suas atividades, observado o ordenamento jurídico brasileiro.

Artigo 10 - A Igreja Católica, em atenção ao princípio de cooperação com o Estado, continuará a colocar suas instituições de ensino, em todos os níveis, a serviço da sociedade, em conformidade com seus fins e com as exigências do ordenamento jurídico brasileiro.

Artigo 11 - §1ㅇ․ O ensino religioso, católico e de outras confissões religiosas, de matrícula facultativa, constitui disciplina dos horários normais das escolas públicas de ensino fundamental, assegurado o respeito à diversidade cultural religiosa do Brasil, em conformidade com a Constituição e as outras leis vigentes, sem qualquer forma de discriminação.

Artigo 14 - A República Federativa do Brasil declara o seu empenho na destinação de espaços a fins religiosos, que deverão ser previstos nos instrumentos de planejamento urbano a serem estabelecidos no respectivo Plano Diretor.

Como esses artigos normativos demonstram, o princípio da laicidade positiva, do pluralismo religioso, da distinção entre Estado e religião e da cooperação entre a Igreja e a sociedade e o 
Victor Sales Pinheiro \& Victor Cláudio Araújo Picanço Da Silva: A legitimidade constitucional do ensino religioso confessional em escolas públicas no Brasil: análise da ação direta de inconstitucionalidade 4.439 a partir da laicidade positiva em Bento XVI

Estado estão claramente enraizados nele. Esse Acordo intenta, claramente, garantir a legitimidade da presença da Igreja no espaço público, bem como reconhece o papel colaborativo exercido pelas religiões junto à sociedade e à missão estatal.

E é precisamente neste contexto que se precisa enfocar o caso jurídico do ensino religioso em escola pública, cuja legitimidade constitucional foi questionada pela PGR na ADI 4439, que se passa a analisar.

\section{A QUESTÃO JURÍDICA: O ENSINO RELIGIOSO CONFESSIONAL EM ESCOLAS PÚBLICAS NO BRASIL}

Delineados o horizonte do problema da secularização (seção 2) e o alcance do direito à liberdade religiosa no contexto da laicidade positiva de Bento XVI (seção 3), pode-se analisar, com propriedade, nesta seção, a questão jurídica que mobiliza este Artigo: a legitimidade constitucional do ensino religioso confessional, a partir da ADI 4439. O objetivo é ressaltar, neste caso jurídico relevante, a principal distinção conceitual apresentada, a de laicidade e laicismo.

\subsection{A ADI 4439 e os modelos de ensino religioso}

A Ação Direta de Inconstitucionalidade (ADI) № 4.439 foi proposta pela Procuradoria-Geral da República (PGR) perante o Supremo Tribunal Federal (STF), em 2010, para assentar que o ensino religioso em escolas públicas só poderá ter natureza não confessional, sendo proibida a admissão de professores na condição de representantes de confissões religiosas, consoante o preceito constitucional da laicidade do Estado.

Para tanto, a ADI propugna a aplicação da técnica de interpretação conforme à Constituição aos seguintes dispositivos legais transcritos abaixo, especialmente no que concerne ao mandamento constitucional: "O ensino religioso, de matrícula facultativa, constituirá disciplina dos horários normais das escolas públicas de ensino fundamental” (CF, artigo 10, §1ํ).

Lei de Diretrizes e Bases da Educação - LDB (da Lei № 9.394/96)

Art. 33. O ensino religioso, de matrícula facultativa, é parte integrante da formação básica do cidadão e constitui disciplina dos horários normais das escolas públicas de ensino fundamental, assegurado o respeito à diversidade cultural religiosa do Brasil, vedadas quaisquer formas de proselitismo. 
ISSN 0719-7160

$\S 1$ 응 Os sistemas de ensino regulamentarão os procedimentos para a definição dos conteúdos do ensino religioso e estabelecerão as normas para a habilitação e admissão dos professores.

$\S 2$ O Os sistemas de ensino ouvirão entidade civil, constituída pelas diferentes denominações religiosas, para a definição dos conteúdos do ensino religioso.

Acordo entre o Governo da República Federativa do Brasil e a Santa Sé (Decreto no 7.107/2010)

Artigo 11.

§1ㅇ․ O ensino religioso, católico e de outras confissões religiosas, de matrícula facultativa, constitui disciplina dos horários normais das escolas públicas de ensino fundamental, assegurado o respeito à diversidade cultural religiosa do Brasil, em conformidade com a Constituição e as outras leis vigentes, sem qualquer forma de discriminação.

O objetivo da ADI é o de definir que o ensino religioso em escolas públicas pode ter natureza tão somente não confessional. Subsidiariamente, caso fosse tido por incabível esse primeiro pedido, a PGR requer a declaração de inconstitucionalidade com redução parcial de texto da expressão "católico e de outras confissões religiosas", constate do mesmo artigo do Acordo.

Segundo a PGR, o único modo de compatibilizar a oferta da disciplina de ensino religioso nas escolas públicas com o princípio da laicidade constante da Constituição seria a adoção do modelo não confessional.

Nesse modelo, a disciplina é ministrada por professores regulares do sistema público de educação e se consubstancia na exposição dos aspectos doutrinários, históricos, práticos e sociais das confissões religiosas e mesmo das não-religiosas, como o ateísmo e o agnosticismo, de forma a garantir a neutralidade estatal em matéria de religião. Trata-se, portanto, de modelo de ensino laico de religião, e não de ensino religioso confessional de uma crença específica. A questão problematizada por este Artigo é se o direito à liberdade religiosa não inclui o direito a ter acesso, em escolas públicas, ao ensino propriamente religioso, confessional, a fim de exercer a própria religião.

Como se estabelece abaixo, ao concordar com o voto do Min. Alexandre de Moraes, defende-se que o direito ao conhecimento acerca da religião não se confunde com o direito à liberdade religiosa, a qual, na sua dimensão positiva e prestacional, implica a oferta pública da disciplina ensino religioso, sendo esta a intenção do texto constitucional, ratificado pelo STF.

\subsection{O laicismo do voto Ministro Barroso: negação do princípio da cooperação entre estado e religião e privatização da religião}


Victor Sales Pinheiro \& Victor Cláudio Araújo Picanço Da Silva: A legitimidade constitucional do ensino religioso confessional em escolas públicas no Brasil: análise da ação direta de inconstitucionalidade 4.439 a partir da laicidade positiva em Bento XVI

No voto do Ministro Barroso, são sublinhados os seguintes elementos constitucionais, que merecem ser harmonizados: (1) o princípio da laicidade; (2) neutralidade em matéria religiosa; (3) o direito à liberdade religiosa e o ensino religioso facultativo nas escolas públicas de ensino fundamental.

(1) Por causa do princípio da laicidade, rechaçou, de plano, a compatibilidade da natureza confessional ou interconfessional do ensino religioso com a Constituição, posto que seriam modelos frontalmente antagônicos ao princípio da laicidade. Para o ministro, a própria previsão constitucional do ensino religioso em escolas públicas seria, ela mesma, uma exceção ao princípio da laicidade, pois aproximaria em algum grau o Poder Público e a religião, devendo esta cláusula ser interpretada restritivamente.

Ora, essa interpretação restritiva parece contrária à lógica expansiva dos direitos fundamentais, assim como a interpretação sistemática do direito à liberdade religiosa, no contexto da Constituição. Como demonstra Weingarten Neto (2016; 2007), o artigo em discussão não é, de modo algum, uma exceção no tratamento constitucional da liberdade religiosa; ao contrário, tratase de uma das mais de 80 dimensões desse multifacetado direito fundamental, que engloba tanto uma dimensão subjetiva (individual, de cada cidadão, e coletivo, das igrejas), quanto objetiva (princípios da separação, não confessionalidade, cooperação, solidariedade e tolerância).

Ao enfatizar, exclusivamente, os princípios da separação entre Estado e religião e da não confessionalidade do Estado, O Ministro Relator restringe a dimensão objetiva do direito constitucional à liberdade religiosa, excluindo o princípio da cooperação do Estado com as igrejas, ao reconhecer o bem da religião e facilitar a sua ação proselitista, na promoção e difusão desse direito, como no caso específico do ensino religioso confessional.

Como se percebe, o Ministro Relator adere aos princípios da concepção laicista, nos termos explicitados na seção anterior, defendendo a separação radical de Estado e religião, devendo esta última restringir-se exclusivamente ao espaço privado. Segundo essa conceoção laicista, o Poder Público não deve promover a religião como um direito fundamental que constituiu o bem comum da sociedade, mas apenas tolerá-lo na sua manifestação exclusivamente individual.

Em seguida, o Ministro Barroso aborda o conteúdo jurídico da laicidade, que consistiria nos seguintes elementos: (1.1) separação formal entre Igreja e Estado; (1.2) neutralidade em matéria religiosa; e (1.3) garantia da liberdade de religião. 


\section{ISSN 0719-7160}

(1.1) A separação formal entre Igreja e Estado, por sua vez, teria três dimensões: (1.1.1.) a dimensão institucional, que vedaria qualquer arranjo político no sentido de fundir Igreja e Estado; (1.1.2.) a dimensão pessoal, que ensejaria a proibição de admissão de representantes de entidades religiosas, em função desta condição, como agentes públicos; e (1.1.3.) a dimensão simbólica, que impediria que o Estado adotasse símbolos de identificação de credo religioso. Assim, o modelo confessional ou interconfessional violaria a separação formal entre Estado e religião, pois resultaria em identificação institucional entre o Estado e a religião.

(2) Quanto à neutralidade em matéria religiosa, sustentou o ministro que tal instituto veda o estabelecimento pelo Estado de preferências ou discriminação entre as confissões religiosas. Essa proibição se configura de três modos, impedindo que o Estado: (2.1) favoreça, promova ou subvencione determinada religião (neutralidade como não-preferência); (2.2.) obstaculize, discrimine ou embarace religiões ou mesmo posições não-religiosas (neutralidade como não embaraço); (2.3.) tenha a sua orientação determinada por posições religiosas ou não-religiosas (neutralidade como não-interferência).

Concluiu o ministro que, tendo o Brasil uma variedade tão grande de grupos religiosos, seria impossível ao Estado abrir turmas específicas que garantissem a todos os estudantes que recebessem instrução segundo suas crenças. Dessa forma, somente as religiões já hegemônicas teriam capacidade para formar e oferecer professores para as escolas públicas, o que configuraria favorecimento às religiões majoritárias e desprestígio às posições religiosas ou não-religiosas minoritárias.

(3) Em relação à garantia da liberdade religiosa, assentou que, por um lado, se trata (3.1.) de direito fundamental autônomo, que integra o universo de escolhas existenciais do indivíduo e expressão da dignidade humana, e, por outro, (3.2.) do conteúdo básico da laicidade.

Afirma o ministro que em sua dimensão objetiva, a liberdade religiosa exige que o Estado seja responsável por promover a tolerância e o respeito mútuo entre os adeptos dos diferentes credos religiosos e não-religiosos. Dessa forma, o ensino religioso confessional ou interconfessional faz com que os estudantes adeptos de religiões que não são representadas nas aulas se sintam intimidados a expressar suas preferências religiosas, podendo mesmo estigmatizá-los, mais ainda quando se trata do ensino fundamental, que alcança crianças e adolescentes. 
Victor Sales Pinheiro \& Victor Cláudio Araújo Picanço Da Silva: A legitimidade constitucional do ensino religioso confessional em escolas públicas no Brasil: análise da ação direta de inconstitucionalidade 4.439 a partir da laicidade positiva em Bento XVI

Consoante o pleito da PGR, o ministro destacou que somente o ensino religioso não confessional, ministrado de forma plural, objetiva e neutra (sem valoração moral da doutrina religiosa) preservaria o princípio da laicidade e atenderia aos ditames da liberdade religiosa.

Ademais, considerou atentatória aos princípios da laicidade, igualdade e da liberdade religiosa a interpretação do referido artigo constitucional que permitisse o ensino religioso em escolas públicas, ainda não houvesse ônus para o Estado. Segundo o relator, abrir os espaços públicos para que as próprias entidades religiosas ministrassem o conteúdo da disciplina não seria uma atitude neutra, mas favoreceria as denominações com maior capacidade de organização e mobilização.

Ao cabo, tratando das possíveis consequências práticas de seu voto, sugeriu a adoção das seguintes providências: que o Ministério da Educação (MEC) definisse parâmetros curriculares nacionais para o ensino religioso, como forma de orientar os órgãos estaduais e municipais; que, em absolutamente nenhuma hipótese, a contratação de professor para ministrar a disciplina dependesse de qualquer ato de vontade de entidade religiosa; a fim de garantir a facultatividade da disciplina, que fosse vedada a matrícula automática dos estudantes na matéria; que fosse oferecida alternativa pedagógica ao estudante que não optasse pelo ensino religioso, de modo a atingir a carga horária mínima prevista na LDB; que o ensino religioso fosse ministrado em horário específico, sendo proibida sua abordagem transversal, isto é, que seu conteúdo fosse tratado nas disciplinas convencionais; e que fosse garantido aos alunos matriculados na disciplina a opção de se desligarem a qualquer tempo.

\subsection{A laicidade positiva do voto do Ministro Moraes: a dimensão objetiva e prestacional do direito à liberdade religiosa}

O Ministro Alexandre de Moraes opõe-se aos argumentos do Ministro Relator, votando para que a $A D I$ em exame fosse julgada improcedente, conforme as seguintes conclusões: (1) o cotejo entre o princípio da laicidade e o direito à liberdade religiosa, conjuntamente à determinação expressa no já citado art. 210, §1ํㅡ, da CF, autorizaria o ensino religioso confessional das diversas doutrinas religiosas nas escolas públicas, mediante regulamentação do Ministério da Educação; (2) o reconhecimento do direito subjetivo ao ensino religioso, de matrícula voluntária, como disciplina dos horários normais das instituições públicas de nível fundamental, a ser ministrada de acordo com suas confissões religiosas, por seus integrantes, contratados a partir de 


\section{ISSN 0719-7160}

chamamento público; por fim, (3) a referida contratação, preferencialmente, deverá ser sem ônus ao Poder Público.

No início de seu voto, o ministro buscou ampliar a discussão. Nesse sentido afirmou que o tema em debate não se limitava às noções de laicidade e de liberdade de crença, mas englobava também questões relativas à liberdade de expressão de pensamento, à luz da tolerância e da diversidade de opiniões.

Com efeito, segundo o ministro, a tolerância que vem sendo alegadamente defendida no âmbito da ADI tem como mote principal a diversidade de opiniões em sala de aula, com liberdade de manifestação para as mais distintas concepções políticas, ideológicas, de gênero e demais formas de pensamento. Porém, ao tratar de concepções religiosas, parece se pretender transformar tal tolerância em censura prévia à livre manifestação de crenças em salas de aula, com a mutação do ensino religioso em disciplina neutra, cuja neutralidade, imposta pelo Estado, representa violação à liberdade religiosa.

Como se viu na seção anterior, essa posição é exatamente a que distingue a laicidade positiva do lacisimo, que impõe uma visão de mundo secularista, de que todas as religiões se equivalem, gerando indiferença religiosa e restringindo a prática religiosa ao espaço privado, como se qualquer cooperação do Poder Público com a religião o tornasse confessional, privilegiasse algum credo específico e ferisse o princípio da laicidade (SARLET; MARONINI; MITIDIERO, 2015. p.512)

Assim, o Ministro Moraes considera que o objetivo da ADI consiste em limitar o direito subjetivo constitucional do estudante que já professa alguma crença a ser matriculado na disciplina de ensino religioso em conformidade com sua própria confissão. Essa definição parece ser a mais acertada acerca da problemática estudada: o estudante tem o direito constitucional subjetivo explícito de poder se matricular na disciplina de ensino religioso, exercendo o seu direito fundamental de liberdade religiosa. A contrapartida objetiva desse direito é o dever de as escolas públicas o ofertarem em horário regular.

Como a religião está na seara dos direitos individuais de liberdade - como a liberdade de consciência e de expressão -, ela não pode ser imposta coercitivamente pela autoridade público, razão pela qual o estudante tem o direito de não se matricular nesta disciplina, caso não professe a confissão ministrada, por pertencer a outra denominação religiosa ou por não ter religião. 
Victor Sales Pinheiro \& Victor Cláudio Araújo Picanço Da Silva: A legitimidade constitucional do ensino religioso confessional em escolas públicas no Brasil: análise da ação direta de inconstitucionalidade 4.439 a partir da laicidade positiva em Bento XVI

Nesse contexto, insurge-se o ministro contra essa tentativa de limitar o direito à liberdade religiosa, ao observar que, subjacente à iniciativa da PGR, está a ideia de certos grupos sociais de que, pelo fato de a maioria das confissões religiosas sustentarem posições tidas como conservadoras, seria perigoso que propagassem suas doutrinas em sala de aula, mesmo para estudantes que voluntariamente se matriculassem na disciplina.

Por conseguinte, entender como procedente a interpretação proposta pela ADI seria impor censura prévia às opiniões religiosas diversas. Ademais, significaria na prática a criação artificial de uma doutrina religiosa oficial, com conteúdo neutro e meramente descritivo. Essa concepção é exatamente a do laicismo militante, que visa a neutralizar a religião, tida a priori como nociva às liberdades públicas (WEIMGARTEN NETO; SARLET, 2016. p. 98-99).

A fundamentação do voto baseou-se em três elementos: (1) a especial relação entre o Estado laico e a liberdade de religião; (2) a singularidade - constitucionalmente prevista consistente em a disciplina de ensino religioso ter de ser ministrada de acordo com os dogmas das confissões religiosas e (3) o princípio da igualdade entre todas as crenças religiosas.

Dessa forma, (1) quanto à conexão entre laicidade e liberdade religiosa, destacou a tradição constitucional republicana brasileira, que a traçou em dois âmbitos: por um lado, visando (1.1.) a proteger o indivíduo e a instituição religiosa da interferência do Estado; e, por outro, (1.2.) a garantir a independência do Estado em relação aos dogmas religiosos.

Em seguida, (2) procurou delinear a intenção original dos constituintes ao inserirem na formulação da Constituição a previsão do ensino religioso nas escolas públicas de ensino fundamental, com matrícula facultativa e como disciplina dos horários normais. Tal previsão, sublinhou, representa uma opção tomada pelo Poder Constituinte: a disciplina deverá ser implementada nas escolas públicas. Logo, a interpretação que leve à conclusão de que o ensino religioso poderia não ser ofertado não é compatível com a literalidade inconteste do texto constitucional.

Por sua vez, reafirmou que o ensino religioso não se trata de imposição estatal, mas de direito subjetivo constitucional do estudante que tem por núcleo fundamental os dogmas de fé cada uma das confissões religiosas, não sendo possível ser ministrado de forma neutra.

Para o ministro, o ensino religioso se distingue de todos os demais ramos de saber, seja pelos seus dogmas, métodos, postulados ou conclusões, o que seria impeditivo para a sua neutralidade. Portanto, a forma pela qual deve ser ministrada a disciplina é a confessional, ou seja, 


\section{ISSN 0719-7160}

aquela em que é lecionada de acordo com a confissão religiosa voluntariamente manifestada pelo estudante. Pretender o contrário, seria exigir a imposição pelo Estado de um conteúdo fictício, que mistura as crenças de diversas religiões, ou confundir o ensino religioso com a disciplina de história, filosofia ou ciência das religiões.

Em relação à singularidade do ensino religioso, como já destacado acima, ratificou que se trata de disciplina excepcional e plenamente compatível com o princípio da laicidade do Estado. Com efeito, garantir que a frequência à disciplina fosse facultativa, ao mesmo tempo em que se exigisse que fosse neutra e descritiva, seria um contrassenso. Afinal, há outras disciplinas, como Filosofia, História, Sociologia a Geografia, que fazem abordagens dessa natureza, mas cuja frequência é obrigatória.

Assim, por meio de uma análise sistemática e histórica, demonstrou que a relação entre Igreja e Estado, no Brasil, embora seja de separação formal, permite a colaboração no interesse público, enumerando os dispositivos constitucionais e casos práticos que ilustram essa parceria.

Argumentou que todas as constituições democráticas do período republicano brasileiro trouxeram previsão semelhante, e mesmo as constituições do Estado Novo e a de 1967. Outrossim, na Assembleia Nacional Constituinte, realizada entre 1987-1988, as tentativas de supressão do dispositivo foram todas rejeitadas, inclusive a proposta que admitia o ensino religioso, mas impunha a sua não confessionalidade.

Adiante, o ministro insistindo na distinção do ensino religioso, abordou detidamente a sua epistemologia, a fim de assentar a impossibilidade mesma de o conteúdo da disciplina ser neutro. Nesse diapasão, a partir do recurso a certas referências teóricas, procurou deixar claro que a História, a Filosofia e a Ciência das religiões não se confundem com o ensino religioso, uma vez que este trata de questões de fé.

A título de exemplo, afirmou que os estudantes que buscam o ensino religioso católico querem entender o mistério da Santíssima Trindade, em razão da fé, não sendo suficiente a mera descrição neutra do tópico teológico. Essa atitude consistiria, na prática, em negar o ensino religioso.

Como se percebe com clareza, o Ministro Moraes discerne a laicidade positiva - adotada pela Constituição Brasileira - do laicismo militante que neutraliza a colaboração do Estado com a religião, visando a neutralizá-la pela adoção de um ensino laico que a reduz a um fenômeno meramente antropológico e cultural. O princípio da laicidade como cooperação é claramente 
Victor Sales Pinheiro \& Victor Cláudio Araújo Picanço Da Silva: A legitimidade constitucional do ensino religioso confessional em escolas públicas no Brasil: análise da ação direta de inconstitucionalidade 4.439 a partir da laicidade positiva em Bento XVI

descrito neste excerto de doutrinadores constitucionais respeitados (BRANCO, MENDES, COELHO, 2009, p.462-3):

\begin{abstract}
A laicidade do Estado não significa, por certo, inimizade com a fé. Não impede a colaboração com confissões religiosas, para o interesse público (CF, art. 19, I), A sistemática constitucional acolhe, mesmo, expressamente, medidas de ação conjunta dos Poderes Públicos com denominações religiosas e reconhece como oficiais certos atos praticados no âmbito de cultos religiosos, como é o caso da extensão de efeitos civis ao casamento religioso. (...)

O reconhecimento da liberdade religiosa pela Constituição denota haver o sistema jurídico tomado a religiosidade como um bem em si mesmo, como um valor a ser preservador e fomentado. Afinal, as normas jusfundamentais apontam para valores tidos como capitais para a coletividade, que devem não somente ser conservados e protegidos, como também promovidos e estimulados.
\end{abstract}

Encaminhando-se para o final de seu voto, passou a balizar (3) as consequências práticas da regulamentação do ensino religioso, consoante o pluralismo e o princípio da igualdade entre todas as crenças religiosas. Primeiramente, registrou que, ao disciplinar o conteúdo da matéria, deve ser evitado o dirigismo estatal, (3.1.) tanto no sentido de optar pelo conteúdo programático de uma única crença (uniconfessionalismo), o que representaria privilégio a determinada crença e violaria a laicidade; (3.2.) quanto no sentido de instituir conteúdo oficial para a matéria (restringindo-se aos aspectos históricos, culturais, sociais, filosóficos etc. das diversas religiões) e assumir a tarefa de ministrá-la, por violar o princípio da liberdade religiosa.

Por fim, na execução de seu mister, o Estado deveria se ater ao princípio da igualdade, estabelecendo normas administrativas que possibilitassem parcerias voluntárias, sem transferência de recursos financeiros, com todas as confissões religiosas que se interessassem, sugerindo a realização de chamamentos públicos.

Nessa linha, o ministro chamou a atenção para o fato de que regulamentação semelhante já existe em relação à saúde e à área penitenciária, nas quais é prestada assistência religiosa.

\title{
4.4. Resolução do caso: laicidade como respeito à liberdade e à identidade religiosa do povo brasileiro
}

É digno de registro que, após a leitura do voto do Ministro Alexandre de Moraes, o Ministro Luís Roberto Barroso, relator, fez as seguintes observações: na audiência pública realizada, dois terços das confissões religiosas presentes se manifestaram a favor do modelo de ensino religioso 


\section{ISSN 0719-7160}

não-confessional, o que denotaria que tal modelo não violaria a liberdade religiosa; a religião deve se restringir à vida privada, não havendo lugar para ela no espaço público, cabendo ao Estado tão somente expor as doutrinas de cada religião; a experiência da colaboração entre Estado e religião na saúde e na área penitenciária não serve de parâmetro, pois os beneficiados são adultos, maiores e capazes, não crianças e adolescentes, que não têm discernimento para essas escolhas, sendo incompatível com a Constituição a contratação de alguém para o cargo de professor de escola pública devido ao seu vínculo com determinada religião e não por concurso público. Após, acrescentou que a possibilidade de haver um ministro de instituição religiosa dentro de sala de aula afrontava a ideia de laicidade e do lluminismo.

Nesta consideração final do Ministro Relator, além de reforçar sua posição laicista de separação radical entre Estado e Religião e de restrição do direito à liberdade religiosa à esfera exclusivamente privada, evidencia-se a sua filiação filosófica ao lluminismo, o que seria contraditório com a alegação de que o ensino laico seria neutro. Pelo contrário, trata-se de uma posição muito situada, historicamente, nos ideais iluministas e positivistas do republicanismo anticatólico dos séculos XVIII e XIX, que se voltavam contra a autoridade pedagógica da Igreja (JOHNSON, 1994, p. 117-8).

Também merece nota o voto do Ministro Gilmar Mendes, ao fazer referência à herança cultural de matriz cristã do Brasil. Aponta o ministro o fato de a Constituição invocar a Deus em seu preâmbulo e que este elemento, ainda que careça de força normativa, tem por função formar a identidade pela qual a Constituição legitima a si mesma. E ressalta a inegável presença de Deus em nosso cotidiano, nos nomes dos estados e municípios, em monumentos, na moeda nacional, nos símbolos presentes nos órgãos públicos etc. Todas essas manifestações constituem parte da cultura brasileira, não cabendo inferir daí a existência de parcialidade ou ofensa à neutralidade.

Esses elementos religiosos na vida pública brasileira - por exemplo, a inscrição "Deus seja louvado" na cédula da moeda brasileira, o Real, e os símbolos religiosos, como o Crucifixo, em órgãos públicos - constituem manifestações de laicidade positiva, de respeito pela cultura e identidade que formou o povo brasileiro, que não deve ser alvo de um laicismo militante, sob o risco de ultrajar o direito constitucional à liberdade religiosa.

A divergência aberta pelo Ministro Alexandre de Moraes, que defendeu a laicidade positiva nos moldes do pensamento de Bento XVI, foi acompanhada pelos Ministros Edson Fachin, Gilmar Mendes, Dias Toffoli, Ricardo Lewandowski e Carmem Lúcia, que acrescentaram ainda outros 
Victor Sales Pinheiro \& Victor Cláudio Araújo Picanço Da Silva: A legitimidade constitucional do ensino religioso confessional em escolas públicas no Brasil: análise da ação direta de inconstitucionalidade 4.439 a partir da laicidade positiva em Bento XVI

argumentos favoráveis à defesa da liberdade religiosa. Por sua vez, o Relator foi seguido pelos Ministros Rosa Weber, Luiz Fux, Marco Aurélio Mello e Celso de Melo.

Desse modo, por seis votos a cinco, foi julgada improcedente a ADI № 4.439 e o ensino religioso confessional em escola pública foi considerado constitucionalmente legítimo, interrompendo a ameaça ao direito de liberdade religiosa que o gesto laicista da PGR suscitou.

\section{CONSIDERAÇÕES FINAIS}

Este trabalho buscou demonstrar de que forma a Igreja lidou com as novas questões concernentes à relação entre Estado e religião surgidas na contemporaneidade, cujo principal pilar é a laicidade a liberdade religiosa, a partir da articulação dos argumentos jurídicos dos votos dos Ministros Barroso e Moraes, classificando-os, respectivamente, a partir dos conceitos de laicismo e laicidade positiva, estudados a partir do Magistério de Bento XVI.

O objetivo do Artigo foi o de promover um diálogo entre Direito e Religião, explicitando como os conceitos elaborados pela teologia política de Bento XVI compreendem para a explicitação dos argumentos jurídicos dos Ministros do Supremo Tribunal Federal, na discussão de um tema jurídico e religioso fundamental, qual seja, o da legitimidade constitucional do ensino religioso confessional em escola pública.

Esse problema foi deflagrado exatamente a partir do Acordo entre o Brasil e a Santa Sé, de 2010, que institui um claro modelo de laicidade positiva, ao prever a colaboração da Igreja no ensino religioso público, contribuindo para a promoção de um direito humano fundamental.

Para apresentar o quadro completo do problema jurídico e teológico, optou-se por primeiro contextualizar o problema do pluralismo religioso na formação do Estado Moderno e do pluralismo epistemológico no tratamento da questão da secularização Assim, apresentaram-se modelos de relação Estado e religião, descrevendo-se como se deu a afirmação da laicidade e a sua correlação com os direitos humanos, especialmente o direito à liberdade religiosa, tanto por parte do Estado, quanto por parte da Igreja Católica.

Após, verificou-se que há uma disputa conceitual intensa sobre o termo "laicidade", ora entendido como uma postura legítima do Estado, ora como uma abordagem antirreligiosa. Observou-se também que tal indefinição também é encontrada nas manifestações da hierarquia eclesiástica. 
ISSN 0719-7160

Desta forma, frente às investidas laicistas, que, a pretexto de defender a laicidade do Estado, objetivam marginalizar a religião, no pontificado de Bento XVI foi elaborado o termo "laicidade positiva", que busca, ao mesmo tempo em que resguarda uma legítima distinção entre a ação eclesial e a atuação estatal, garantir a presença do elemento religioso no espaço público, bem como promover uma atitude de colaboração para com o Poder Público.

Neste sentido, a partir da análise de pronunciamentos, manifestações e atos oficiais, foi demonstrado como o Pontífice atuou para materializar esta definição e torná-la diretriz para a atuação diplomática da Santa Sé, que culminou no referido Acordo com o Estado Brasileiro.

Ademais, pôde-se analisar, com clareza, a consonância do conceito de laicidade positiva de Bento XVI na argumentação do Ministro Moraes, que apresentou a divergência na votação da ADI 4439 e foi seguido pela maioria dos ministros.

Por outro lado, também foi evidenciada a abordagem laicista do voto vencido do Relator Barroso, que defende uma posição iluminista que reduz o direito à liberdade religiosa ao direcionamento secularista, estabelecendo uma posição oficial e exclusiva em matéria religiosa por parte do Estado. Ao invés de salvaguardar o direito que o cidadão tem de receber o ensino religioso confessional, caso queira, em consonância com a sua livre consciência, tal postura exigira dele um ensino secularista que não é, de maneira nenhuma, neutro, mas que neutraliza o bem da religião, reduzindo-o a uma mera manifestação antropológica, sociológica e cultural.

Por fim, considera-se positivo o debate que o Supremo Tribunal Federal encetou nesta matéria, pois houve real contraditório na argumentação dos Ministros, assim como foram ouvidas entidades representativas da sociedade civil, religiosas ou não, o que assinala um amadurecimento significativo do debate público brasileiro sobre a questão premente do direito à liberdade religiosa, constitutivo da dignidade humana e do bem comum.

\section{REFERÊNCIAS BIBLIOGRÁFICAS}

ALMEIDA, Fábio Portela Lopes de. Liberalismo Político, Constitucionalismo e Democracia - A questão do ensino religioso nas escolas públicas. Belo Horizonte: Argvmentvm, 2008.

ALLEN JR, John. Extracts from Sarkozy on church/state relations in France. The National Catholic Report, 2008 [online] Disponível em: <https://www.ncronline.org/news/extracts-sarkozychurchstate-relations-france?splash=>. Acesso em 04 de abril de 2018.

ARAUJO, Luiz Bernardo Leite; MARTINEZ, Marcela Borges; PEREIRA, Taís Silva. Esfera pública e secularismo. Ensaios de filosofia política. Rio de Janeiro: UERJ, 2012. 
Victor Sales Pinheiro \& Victor Cláudio Araújo Picanço Da Silva: A legitimidade constitucional do ensino religioso confessional em escolas públicas no Brasil: análise da ação direta de inconstitucionalidade 4.439 a partir da laicidade positiva em Bento XVI

AYUSO, Miguel. La Constiutución Cristiana de los Estados. Barcelona: Ediciones Scire, S.L., 2008.

BASSET, Ursula C. Pragmática de los términos 'laicidad', 'laicismo' y 'autonomia' en el Magisterio Pontificio de Benedicto XVI. In: HERRERA, Daniel A.; CURCI, Juan I. Pérez (org.) IV Jornadas internacionales de derecho natural. Ley natural y legítima laicidad. Buenos Aires: EDUCA, 2010. pp.447-474.

BENTO, António; ROSA, José Maria Silva; DOMINGUES, José António (org.). Secularização e teologia política. Lisboa: Comenta, 2019.

BRANCO, Paulo; MENDES, Gilmar; COELHO, Inocêncio. Curso de direito constitucional. 4ạ ed. ampl. São Paulo: Saraiva, 2009.

BRASIL. DECRETO № 7.107, de 11 de fevereiro de 2010. Promulga o Acordo entre o Governo da República Federativa do Brasil e a Santa Sé relativo ao Estatuto Jurídico da Igreja Católica no Brasil, firmado na Cidade do Vaticano, em 13 de novembro de 2008. Brasília, DF, 2009. Disponível em: <http://www.planalto.gov.br/ccivil_03/_ato2007-2010/2010/decreto/d7107.htm>. Acesso em 27 de abril de 2018.

BRODBECK, Rafael Vitola. 'Das relações entre Igreja e Estado segundo a Doutrina Católica.' In: Jesus Cristo: Rei do Universo. Belo Horizonte: Edições Cristo Rei, 2016.

CARTABIA, Marta; SIMONICINI, Andrea (org.). La legge di re Salomone. Ragione e diritto nei discorsi di Benedetto XVI. Milano: BUR, 2013.

CATROGA, Fernando. Entre Deuses e Césares: secularização, laicidade e religião Civil. Coimbra: Editora Almedina, 2006.

CINQUINA, Balmaseda. 'La antropologia de la Gaudium et spes en torno a la laicidade, Karol Wotyla y Juan Pablo Magno'. In: In: HERRERA, Daniel A.; CURCl, Juan I. Pérez (org.) IV Jornadas internacionales de derecho natural. Ley natural y legítima laicidad. Buenos Aires: EDUCA, 2010. pp. 423-436.

CIFUENTES, Rafael Llano. Relações entre Igreja e Estado. São Paulo: José Olympio, 1989.

CONTRERAS, Francisco José. 'Laicidad, razón pública y lei natural'. In: Liberalismo, Catolicismo y Ley Natural. Madrid: Encuentro, 2013.

DIP, Ricardo. 'O Estado Laico e o Magistério Eclesial: Acolhimento Arrependido da Modernidade ou Apostasia Objetiva das Nações Católicas?' In:____ ; FERNANDES, André Gonçalves. (org.) Laicismo e laicidade no Direito. São Paulo: Quartier Latin, 2017. pp. 271-278 
ISSN 0719-7160

DUMONT, Bernard. Del Laicismo a la Laicidad. In: Revista VERBO - ISSN: 0210-4784 - Madri, núm. 465-466 (2008).

FAZIO, Mariano. Historia de las idea contemporâneas. Una lectura del processo de secularización. Madrid: Rialp., 2012a.

FAZIO, Mariano. Al César lo que es del César. Benedicto XVI y la libertad. Madrid: Rialp, 2012b.

FAZIO, Mariano. La sana laicidad en el pensamiento de Benedicto XVI. In: HERRERA, Daniel A.; CURCI, Juan I. Pérez (org.) IV Jornadas internacionales de derecho natural. Ley natural y legítima laicidad. Buenos Aires: EDUCA, 2010. pp.135-150.

FINNIS, John. Religion and public reasons. Colected Essays of John Finnis. vol. V. Oxford: Oxford University Press, 2011a.

FINNIS, John. Public Reason and moral debate. In: Reason in action. Collected Essays: vol. I. Oxford: Oxford Press, 2011b.

FINNIS, John. Aquinas. Aquinas. Moral, legal and political theory. Oxford: Oxford University Press, 1998.

GEORGE, Robert P. Religious Liberty and Political Morality. In: In defense of Natural Law. Oxford: Oxford University Press, 1999, pp. 125-138.

GUARRIDO, Miguel Ángel. El respeto político a la creencia. Laicidad y laicismo. Madrid: Rialp, 2011. HABERMAS, Jürgen; RATZINGER, Joseph. Dialética da Secularização: sobre razão e religião. 3ạ ed. São Paulo: Ideias \& Letras, 2007.

HOLLENBACH, David. Human dignity in Catholich Thought. In: DÜWELL, Marcus; BRAARVIG, Jens; BROWNSWORD, Roger; MIETH, Dietmar (org.) The Cambridge Companion Handbook of Human Dignity. Cambridge: Cambridge University Press, 2014. pp. 251-259.

JOHNSON, Paul. Tempos modernos. O mundo dos anos 20 aos 80. Rio de Janeiro: Biblioteca do Exército Editora; Instituto Liberal, 1994.

LUÑO, Ángel Rodríguez. Cultura política y consciência Cristiana. Ensayos de ética política. Madrid: Rialp, 2007.

MACHADO, Jónatas E.M. Estado constitucional e neutralidade religiosa. Entre o teísmo e o (neo)ateísmo. Porto Alegre: Livraria do Advogado, 2013.

MARRAMAO, Giacomo. Céu e terra. Genealogia da secularização. São Paulo: UNESP, 1994.

MENOZZI, Daniele. Chiesa e diritti umani. Legge naturale e modernità politica dalla Rivoluzione francese ai nostri giorni. Bologna, II Mulino, 2012. 
Victor Sales Pinheiro \& Victor Cláudio Araújo Picanço Da Silva: A legitimidade constitucional do ensino religioso confessional em escolas públicas no Brasil: análise da ação direta de inconstitucionalidade 4.439 a partir da laicidade positiva em Bento XVI

Organização das Nações Unidas. Declaração Universal dos Direitos Humanos, 1948. Disponível em: <http://www.onu-brasil.org.br/documentos_direitoshumanos.php>. Acesso em 29 de julho de 2015.

OLLERO, Andrés. Religión, racionalidad y política. Granada: Editorial Comares, 2013.

PEREA, Javier Álvarez, El colorante laicista. Madrid: Rialp, 2012.

PINHEIRO, Victor Sales. NEIVA, Horácio Lopes Mousinho. Razão prática, direito e bem comum na teoria da lei natural de John Finnis. Quaestio luris, vol. 12, no. 02, 2019. pp. 240-265.

PINHEIRO, Victor Sales; SOUZA, Elden Borges. 'O laicismo e a teoria da lei natural em Finnis: a religião como bem humano básico'. Arquivo Jurídico. Teresina-PI - v. 3 - n. 1 - p. 2-22 Jan./Jun. de 2016.

RAWLS, John. Liberalismo político. México: Fondo de Cultura, 1995.

RATZINGER, Joseph. Fé, verdade, tolerância. O cristianismo e as grandes religiões do mundo. São Paulo: Instituto Brasileiro de Filosofia e Ciência Raimundo Lúlio, 2007. p.209-232.

RHONHEIMER, Martin. Christianity and Secularity: Past and Present of a Complex Relationship; Benedict XVI's 'Hermeneutic of Reform' and Religious Freedom. In: The common good of constitutional democracy. Essays in political philosophy and on catholic social teaching. Washington: The Catholic University of America Press, 2013. pp.342-454.

ROWLAND, Tracey. A fé de Ratzinger. A Teologia do Papa Bento XVI. São Paulo: Ecclesiae; Instituto de Filosofia Raimundo Lúlio, 2013..

SANTAMARIA, Francisco. A religião sob suspeita. Laicidade e laicismo. São Paulo: Quadrante, 2013. SARKIS, João Marcelo. O ensino religioso nas escolas públicas em pauta no STF. In: DIP; FERNANDES (org.), Laicismo e laicidade no Direito. São Paulo: Quartier Latin, 2017. P. 251-269.

SARLET, Ingo Wolfgang; MARONINI, Luiz Guilherme; MITIDIERO, Daniel. Curso de direito constitucional. 4ạ ed. ampl. São Paulo: Ed. Saraiva, 2015.

SARTO, Pablo Blanco. La teologia de Joseph Ratzinger. Una introducción. Madrid: Palabra; Pelicano, 2011.

VATICANO. Exortação Apostólica Pós-Sinodal Ecclesia in Medio Oriente, 2012. Disponível em: <http://w2.vatican.va/content/benedict-xvi/pt/apost_exhortations/documents/hf_benxvi_exh_20120914_ecclesia-in-medio-oriente.html>. Acesso em 26 de abril de 2018. VATICANO. Discurso do Papa Bento XVI ao Corpo Diplomático Acreditado Junto da Santa Sé para a Troca de Bons Votos de Início de Ano, 2010. Disponível em: <http://w2.vatican.va/content/benedict- 
ISSN 0719-7160

xvi/pt/speeches/2010/january/documents/hf_ben-xvi_spe_20100111_diplomatic-corps.html>. Acesso em 04 de abril de 2018.

VATICANO. Carta Encíclica Caritas in veritate - Sobre o Desenvolvimento Humano Integral na Caridade e na Verdade, 2009. Disponível em <http://w2.vatican.va/content/benedictxvi/pt/encyclicals/documents/hf_ben-xvi_enc_20090629_caritas-in-veritate.html>. Acesso em 15 de maio de 2018.

VATICANO. Encontro com os Membros da Assembleia Geral das Nações Unidas, 18 de abril de 2008a. Disponível em: <https://w2.vatican.va/content/benedictxvi/pt/speeches/2008/april/documents/hf_ben-xvi_spe_20080418_un-visit.html>. Acesso em 04 de abril de 2018.

VATICANO. Cerimónia de Boas-Vindas e Encontro com as Autoridades de Estado no Palácio Eliseu, 12 de setembro de 2008b. Disponível em: <http://w2.vatican.va/content/benedict-xvi/pt/speeches/2008/september/documents/hf_benxvi_spe_20080912_parigi-elysee.html>. Acesso em 04 de abril de 2018.

VATICANO. Audiência Geral, 30 de abril de 2008c. Disponível em: <http://w2.vatican.va/content/benedict-xvi/pt/audiences/2008/documents/hf_benxvi_aud_20080430.html>. Acesso em 04 de abril de 2018. VATICANO. Encontro do Santo Padre com os Jornalistas Antes da Partida do Aeroporto de Roma, 28 de novembro de 2006a. Disponível em :<http://w2.vatican.va/content/benedictxvi/pt/speeches/2006/november/documents/hf_ben-xvi_spe_20061128_intervista.html> Acesso em 26 de abril de 2018.

VATICANO. Audiência Geral, 06 de dezembro de 2006b. Disponível em: <http://w2.vatican.va/content/benedict-xvi/pt/audiences/2006/documents/hf_benxvi_aud_20061206.html>. Acesso em 04 de abril de 2018. VATICANO. Encontro com os Representantes das Ciências - Fé, razão e universidade: Recordações e reflexões, 2006c. Disponível em <https://w2.vatican.va/content/benedictxvi/pt/speeches/2006/september/documents/hf_ben-xvi_spe_20060912_universityregensburg.html>. Acesso em 03 de abril de 2018. VATICANO. Discurso do Santo Padre Durante o Encontro com o Presidente dos Assuntos Religiosos da Turquia, 2006d. Disponível em: <https://w2.vatican.va/content/benedict- 
Victor Sales Pinheiro \& Victor Cláudio Araújo Picanço Da Silva: A legitimidade constitucional do ensino religioso confessional em escolas públicas no Brasil: análise da ação direta de inconstitucionalidade 4.439 a partir da laicidade positiva em Bento XVI

xvi/pt/speeches/2006/november/documents/hf_ben-xvi_spe_20061128_pres-religious-

affairs.html>. Acesso em 04 de abril de 2018.

VATICANO. Lettera di Sua Santità Benedetto XVI al Presidente del Senato Marcello Pera in Occasione del Convegno di Norcia "Libertà e Laicità». 2005. Disponível em <https://w2.vatican.va/content/benedict-xvi/it/letters/2005/documents/hf_ben-

xvi_let_20051015_senatore-pera.html>. Acesso em 04 de dezembro de 2017.

VATICANO. Address of Archbishop Giovanni Lajolo, Secretary For The Holy See's Relations with States at the Pontifical Gregorian University of Rome, 2004a. Disponível em <http://www.vatican.va/roman_curia/secretariat_state/2004/documents/rc_seg-

st_20041203_lajolo-gregorian-univ_en.html>. Acesso em 31 de janeiro de 2018.

VATICANO. Compêndio da Doutrina Social da Igreja, 2004b Disponível em <http://www.vatican.va/roman_curia/pontifical_councils/justpeace/documents/rc_pc_justpeace_d oc_20060526_compendio-dott-soc_po.html>. Acesso em 26 de abril de 2018.

VATICANO. Declaração Dignitatis Humanae sobre a Liberdade Religiosa, 1965. Disponível em $<$ http://www.vatican.va/archive/hist_councils/ii_vatican_council/documents/vat-

ii_decl_19651207_dignitatis-humanae_po.html>. Acesso em 29 de julho de 2015

VATICANO. Carta Encíclica Immortale Dei - Sobre A Constituição Cristã Dos Estados, 1885.

Disponível em <https://w2.vatican.va/content/leo-xiii/pt/encyclicals/documents/hf_Ixiii_enc_01111885_immortale-dei.html>. Acesso em 30 de janeiro de 2018.

WEIMGARTEN NETO, Jayme. Ensino religioso nas escolas públicas: a tensão do caso brasileiro. Revista Latinoamericana de Derecho y Religión, vol. 2, n.1, 2016, pp. 1-31.

WEIMGARTEN NETO, Jayme. SARLET, Ingo Wolfgang. Liberdade religiosa no Brasil com destaque para o marco jurídico-constitucional e a jurisprudência do STF. REPATS - Revista de Estudos e Pesquisas Avançadas do Terceiro Setor, Brasília, v. 3, n. 2, p.59-104, jul-dez, 2016. p. 70.

WEINGARTNER NETO. Liberdade religiosa na constituição - fundamentalismo-pluralismo, crenças e cultos. Porto Alegre: Livraria do Advogado, 2007.

WOODS JR., Thomas. Como a Igreja Católica construiu a Civilização Ocidental. São Paulo: Quadrante, 2011. 
ISSN 0719-7160 